\title{
Comparison of microalgal biomasses as functional food ingredients: Focus on the composition of cell wall related polysaccharides
}

Tom M.M. Bernaerts ${ }^{a}$, Lore Gheysen ${ }^{b}$, Clare Kyomugasho ${ }^{a}$, Zahra Jamsazzadeh Kermani ${ }^{a}$, Stéphanie Vandionant ${ }^{a}$, Imogen Foubert $^{b}$, Marc E. Hendrickx ${ }^{a}$, Ann M. Van Loey ${ }^{a} *^{*}$

Laboratory of Food Technology, Leuven Food Science and Nutrition Research Centre (LFoRCe), Department of Microbial and Molecular Systems $\left(\mathrm{M}^{2} \mathrm{~S}\right)$, Katholieke Universiteit Leuven, Kasteelpark Arenberg 22, Box 2457, 3001 Heverlee, Belgium

Authors are affiliated to:

a Laboratory of Food Technology (member of Leuven Food Science and Nutrition Research Center, LFoRCe), Department of Microbial and Molecular Systems $\left(M^{2} S\right)$, KU Leuven, Kasteelpark Arenberg 22 box 2457, 3001 Heverlee, Belgium

b Laboratory Food and Lipids (member of Leuven Food Science and Nutrition Research Center, LFoRCe), Department of Microbial and Molecular Systems (M²S), KU Leuven Kulak, E. Sabbelaan 53, 8500 Kortrijk, Belgium

* Corresponding author

Fax: +3216321960

Telephone: +32 16321567

E-mail:ann.vanloey@kuleuven.be 


\section{ACCEPTED MANUSCRIPT}

\section{Abstract}

Microalgae are rich in several nutritional and health-beneficial components, showing great potential as functional food ingredients. To this extent, knowledge of the biomass composition is essential in the selection of suitable microalgae species for specific food applications. Surprisingly, although cell wall polysaccharides are generally reported to play a role in functionality, limited attention has been given to the cell wall related polysaccharides of microalgae so far. Therefore, this study aimed to characterize dry biomasses of ten microalgae species with potential as functional food ingredients, with a particular focus on the composition of cell wall related polysaccharides. The investigated species were Arthrospira platensis, Chlorella vulgaris, Diacronema lutheri, Tisochrysis lutea, Nannochloropsis sp., Odontella aurita, Phaeodactylum tricornutum, Porphyridium cruentum, Schizochytrium sp. and Tetraselmis chuii. Lipids, proteins and ash made up a large fraction of the biomasses, except for the freshwater algae C.vulgaris and A.platensis which were mainly composed of proteins and polysaccharides. Generally, low amounts of storage polysaccharides $(2-8 \%)$ were observed in the investigated microalgae species, while extracellular polymeric substances were only present in P. cruentum, O. aurita, C. vulgaris and A. platensis. Cell wall polysaccharides contributed approximately $10 \%$ of the biomass and were composed of heteropolysaccharides, showing at least five different monosaccharides. Moreover, the presence of uronic acids and sulfate groups provides anionic characteristics to the cell wall related polysaccharides of several microalgae. As a result, these polysaccharides show potential to display interesting functionalities as bioactive or technological substances.

\section{Keywords}

Biomass composition - cell wall polysaccharides - exopolysaccharides - monosaccharide - uronic acid - sulfate

\section{Highlights}

Carbohydrates separately quantified as storage-, cell wall- and exo-polysaccharides

Exopolysaccharides were observed in P. cruentum, C. vulgaris, O. aurita, A. platensis

Glucose, galactose, xylose and mannose are dominant sugars in the polysaccharides

Uronic acid and sulfate groups confer anionic characteristics to the polysaccharides 


\section{Abbreviations}

$50 \omega 3$-LC-PUFA omega-3 long chain polyunsaturated fatty acids

51 CWPS cell wall polysaccharides

52 EPMS extracellular polymeric substances

53 EPS extracellular polysaccharides

54 SPS storage polysaccharides

55 UHPH ultra high pressure homogenization

56 


\section{Introduction}

Microalgae are a promising source of several nutritional and health-beneficial components, including omega-3 long chain polyunsaturated fatty acids ( $\omega 3$-LC-PUFA), proteins, minerals and antioxidants. In recent decades, research has been exploring their potential as a functional food ingredient, to enhance the nutritional value of food products [1-3]. Since there is a large number of microalgae species available and the composition of microalgal biomasses largely varies among different species, knowledge on the biochemical composition is required for the selection of suitable microalgae towards specific food applications. However, even for a specific microalga species, variable biomass profiles are reported in different studies. Part of this variability is attributed to differences in cultivation conditions, since many environmental factors such as temperature, salinity and nutrient availability can strongly affect the chemical composition of microalgae [4]. While this allows the optimization of cultivation conditions to maximize the production of specific biomolecules, it also results in an increased complexity in comparing different microalgal biomass profiles. On the other hand, the diverse biomass compositions found in literature can also be attributed to distinct analytical approaches used in different studies. For instance, protein contents can be determined by colorimetric assays or elemental analysis of nitrogen. While the former methods are sensitive to interferences and require pretreatments to completely release intracellular proteins, the latter relies on the use of nitrogen-to-protein conversion factors, but different conversion factors have been used by different authors (ranging from 4.44 to 6.25 ) [5,6]. As a consequence, there is still a demand for studies comparing microalgal biomass profiles using standardized protocols.

The nutritional valuable components of microalgae are stored inside the microalgal cell, which is protected by a cell wall (except for a few species). As a consequence, the cell wall plays an important role as a natural barrier, limiting extraction yields of high-value products or resulting in a low bioavailability of intracellular components [7,8]. In this context, extensive research has been performed on the disruption of microalgal cells, including chemical modifications and mechanical, thermal or ultrasonication processes [9]. Although several treatments proved successful for many microalgae, optimization is still required for species possessing a very rigid cell wall. In recent decades, the use of cell wall degrading enzymes has gained interest as this shows some advantages, such as a minimal impact on the desired nutrients and low energy 


\section{ACCEPTED MANUSCRIPT}

requirements $[7,10,11]$. However, this approach requires the precise knowledge of the cell wall composition, for the appropriate selection of specific cell wall degrading enzymes.

Insight into the composition of the cell wall is not only desired in terms of process optimization, but also because distinct cell wall related polysaccharides might show potential for several biotechnological purposes. To date, commercialization of high value products from microalgae is mainly targeted to $\omega 3$-LCPUFA, antioxidants or pigments, while microalgal polysaccharides are receiving limited attention. This might be due to the lack of knowledge on the composition and structure of cell wall related polysaccharides, with only few studies suggesting the potential of cell wall related polysaccharides for several applications. According to de Jesus Raposo et al. (2015) [12], sulfated polysaccharides of microalgae display various bioactivities, such as antiviral, antioxidant and anti-inflammatory activities. Moreover, exopolysaccharides of the red microalga Porphyridium sp. show unique rheological properties and might therefore be used as thickening agents in food products [13]. Thus, establishing the composition of cell wall related polysaccharides, such as the monosaccharide profile or the degree of sulfation, could increase the functionality of microalgal sources towards several applications.

Cell wall related polysaccharides comprise different types of polymers, including cell wall polysaccharides (CWPS) and extracellular polymers. The latter are generally described as polymers that can be secreted into the surrounding enviromment, such as the cultivation medium. Since the amount of secreted material depends on the growth conditions and time of harvesting, the extracellular polymers can be both found as solubilized polymers in the aqueous phase as well as an external layer still surrounding the microalgal cell. Although many microalgae species and cyanobacteria secrete extracellular polymers into the cultivation medium, the type of secreted material is often unclear in literature, primarily due to distinct terminology. The secreted material is often called EPS, referring to either extracellular polymeric substances, extracellular polysaccharides or exopolysaccharides, although terms as released polysaccharides (RPS), extracellular organic matter (EOM) or algogenic organic matter (AOM) are also commonly used [14,15]. Depending on the definition, different classes of organic macromolecules are included, such as polysaccharides, proteins, nucleic acids, phospholipids and smaller molecules [15]. In this study, a distinction will be made between all polymeric material that can be secreted into the environment (referred 
to as extracellular polymeric substances, EPMS) and polysaccharides that can be secreted (referred to as extracellular polysaccharides, EPS).

To date, information in literature on the amount of cell wall related polysaccharides in microalgae is scarce. content, thus including both storage polysaccharides (SPS) and cell wall related polysaccharides. However, these two types of polysaccharides exhibit different functions in the microalgal cell. The main function of SPS is the storage of energy, providing substrates for metabolic processes and allowing survival of the organism during dark periods. In contrast, cell wall related polysaccharides, comprising CWPS and EPMS, play an important structural role in the microalgal cell. Whereas CWPS provide resistance to turgor pressure, interactions between EPMS of different cells allow the creation of multicellular structures [16]. As a consequence, both types of polysaccharides can contribute to different functional properties of the biomass, depending on their structure and composition. Total carbohydrate contents (in fact expressed as glucoseequivalents due to the use of non-specific colorimetric assays, do therefore not allow the prediction of the potential of microalgal polysaccharides.

Although several authors have reported monosaccharide profiles of microalgae, the composition of the cell wall related polysaccharides of many microalgae is still unknown. On the one hand, some studies presented monosaccharide profiles after hydrolysis of the total biomass $[17,18]$. However, due to possible interference of other components, such as SPS and glycolipids, these results provide only limited information on the cell wall composition. On the other hand, some authors have described the composition of cell wall related polysaccharides, but the results were mostly concerning specific polysaccharide fractions obtained by a selective extraction procedure $[19,20]$. Studies focusing on the polysaccharide composition of the whole cell wall are therefore very limited. Moreover, large variability in cell wall composition has been reported within a genus, a species and even within a strain, which can be due to differences in cultivation conditions or depending on the life stage of the cell [7], further limiting the comparison among the studies available. Therefore, the aim of this study is to apply a universal procedure for extraction of the total cell wall related polysaccharides, including CWPS and EPMS, of commercially available microalgae species followed by a detailed characterization. 


\section{ACCEPTED MANUSCRIPT}

The microalgae species used in this study were selected for their potential as functional food ingredients: Arthrospira platensis, Chlorella vulgaris, Diacronema lutheri, Tisochrysis lutea (formerly listed as Isochrysis galbana), Nannochloropsis sp., Odontella aurita, Phaeodactylum tricornutum, Porphyridium cruentum, Schizochytrium sp. and Tetraselmis chuii. Most of them show interesting nutritional profiles, e.g. containing $\omega 3$-LC-PUFA, proteins rich in essential amino acids and antioxidants. In addition, some of these biomasses have been accepted or authorized under the European novel food regulation, or applications are ongoing. Finally, by selecting these microalgae a diverse taxonomic spectrum was obtained, composed of photoautotrophic eukaryotic species classified as Chlorophyta (C. vulgaris, T. chuii), Rhodophyta (P. cruentum), Haptophyta (D. lutheri, T. lutea), Eustigmatophyta (Nannochloropsis sp.), Bacillariophyta or diatoms (O. aurita, P. tricornutum), one heterotrophic species belonging to Labyrinthulomyceta (Schizochytrium sp.) and one prokaryotic cyanobacterium (A. platensis) [21].

The objective of this study is to provide a fair comparison of ten microalgae species that are of interest for use as functional food ingredients. On the one hand, the microalgae were characterized in terms of biomass composition. On the other hand, the composition of the cell wall related polysaccharides CWPS and EPMS were established, by determining the monosaccharide profile, uronic acid content and sulfate content. All analyses were performed on commercially available dry biomasses, with regard to the application of dried microalgal biomass as a functional ingredient in food products, as food ingredients are generally delivered in a dry form to guarantee long term storage stability. The insights provided by this study can facilitate an appropriate selection of microalgae species for enhancing the nutritional value of food products, as well as revealing their potential as bioactive or biotechnological substances.

\section{Materials and Methods}

\subsection{Microalgal biomass}

Commercially available microalgal biomass was obtained from different companies. Lyophilized biomasses of Nannochloropsis sp. and Tisochrysis lutea were obtained from Proviron (Hemiksem, Belgium). Odontella aurita was purchased from Innovalg (Bouin, France), Tetraselmis chuii from Fitoplancton Marino (Cádiz, Spain) and the cyanobacterium Arthrospira platensis from Earthrise (Irvine, 


\section{ACCEPTED MANUSCRIPT}

CA, USA). Lyophilized biomass of Schizochytrium sp. was kindly donated by Mara Renewables Corporation (Dartmouth, Canada). Spray-dried biomass of Chlorella vulgaris was obtained from Allma (Lisbon, Portugal). Biomasses of Phaeodactylum tricornutum and Porphyridium cruentum were obtained as a wet paste from Necton (Olhão, Portugal) and immediately lyophilized. All biomasses were stored in closed containers at $-80{ }^{\circ} \mathrm{C}$ until use.

Biomass of Diacronema lutheri (CCAP 931/1) was produced in-house. This species was cultured in Wright's Cryptophyte medium in $125 \mathrm{~L}$ pilot-scale tubular airlift photobioreactors. Prior to use, the medium was sterilized by membrane filtration $(0.2 \mu \mathrm{m}$ pore size $)$. The photobioreactors were continuously illuminated $\left(125 \mu \mathrm{mol}\right.$ photons $\left./ \mathrm{m}^{2} \cdot \mathrm{s}\right)$ and the culture was maintained at $\mathrm{pH} 7.5$ by automated $\mathrm{CO}_{2}$ injection. The biomass was harvested at the end of the exponential growth phase by centrifugation, lyophilized and stored at $-80{ }^{\circ} \mathrm{C}$.

Even though no full details on cultivation and harvesting conditions could be provided due to restrictions imposed by some companies, the data obtained will be indicative for dry biomasses towards food applications. Possible deviations from optimal cultivation conditions would generally be noticed from the amount of storage components, such as SPS and lipids, rather than structural components such as cell wall related polysaccharides [4]. However, the obtained biomass profiles correspond well with those reported in literature for the inyestigated microalgae species grown under standard conditions, as extensively described in Section 3.1

\subsection{Characterization of the biomass composition}

\subsubsection{Moisture}

Moisture content of the biomass was determined in triplicate by vacuum-drying as described by Nguyen $e t$ al. (2016) [22]. Briefly, $20 \mathrm{mg}$ of microalgal biomass was dried using a vacuum oven (UNIEQUIP 14452, Planegg, Germany), with sequential drying steps for $1 \mathrm{~h}$ at $0.8,0.6$ and 0.4 bar and for 30 min at 0.2 bar. The difference in weight before and after drying was expressed as a percentage, representing the moisture content. The average moisture content was used in the calculation of the chemical components, being expressed in percentage of total dry matter. 


\section{ACCEPTED MANUSCRIPT}

\subsubsection{Lipids}

Lipid content was determined according to the method optimized by Ryckebosch, Muylaert \& Foubert (2012) [23]. Briefly, $4 \mathrm{~mL}$ methanol, $2 \mathrm{~mL}$ chloroform and $0.4 \mathrm{~mL}$ water were added to $100 \mathrm{mg}$ of dry biomass and the samples were homogenized. Then, $2 \mathrm{~mL}$ chloroform and $2 \mathrm{~mL}$ water were added and the samples were again homogenized. After centrifugation $\left(10 \mathrm{~min}, 750 \mathrm{~g}, 25^{\circ} \mathrm{C}\right)$, the upper aqueous layer was discarded, while the lower solvent layer was collected. The remaining pellet was re-extracted with $4 \mathrm{~mL}$ of chloroform:methanol $(1: 1 \mathrm{v} / \mathrm{v})$ and centrifuged $\left(10 \mathrm{~min}, 750 \mathrm{~g}, 25^{\circ} \mathrm{C}\right)$. The solvent phase was collected and the extraction procedure was repeated on the pellet. All solvent layers were combined and filtered through a layer of sodium sulphate to remove remaining water. The solvent was removed by rotary evaporation and lipids were quantified gravimetrically. Lipid content was determined in triplicate

\subsubsection{Proteins}

Protein content was determined by the Dumas method.Approximately 1-2 mg of biomass was transferred to tin capsules and total nitrogen content was analyzed using an elemental analyzer (Carlo-Erba EA1108, Thermo Scientific, Waltham, MA, USA). Protein content was estimated from total nitrogen content, multiplied by an overall conversion factor of 4.78, as proposed by Lourenço et al. (2004) [5]. The analysis was performed in triplicate.

\subsubsection{Storage polysaccharides}

\subsubsection{Starch, floridean starch and glycogen}

According to literature, starch is present in C. vulgaris, T. chuii and Schizochytrium sp. [24-26], whereas R. cruentum contains floridean starch as SPS [27]. Lastly, the cyanobacterium A.platensis contains glycogen [28]. Since all these SPS are polyglucans with $\alpha-1,4$ and $\alpha-1,6$-linkages, they were quantified using the same procedure, based on the method of Pleissner \& Eriksen (2012) [29]. Briefly, 50-100 mg biomass was washed in MOPS buffer (3-(N-morpholino)propanesulfonic acid, $55 \mathrm{mM}, \mathrm{pH} 7)$ and cells were subsequently disrupted using ultra high pressure homogenization (UHPH) at $250 \mathrm{MPa}$ (Stansted Fluid Power SPCH-10, Harlow, United Kingdom). A single pass was applied for most microalgae, except for the more rigid $C$. vulgaris requiring two passes for full cell disruption. After addition of ethanol and dimethyl 


\section{ACCEPTED MANUSCRIPT}

sulfoxide, the mixtures were boiled for $15 \mathrm{~min}$ at $100{ }^{\circ} \mathrm{C}$ to gelatinize (floridean) starch. Samples were then incubated with thermostable $\alpha$-amylase from Bacillus licheniformis (519 U/mg, Sigma-Aldrich) for $10 \mathrm{~min}$ at $90{ }^{\circ} \mathrm{C}$, followed by incubation with amyloglucosidase from Aspergillus niger (70 U/mg, Sigma-Aldrich) for $1 \mathrm{~h}$ at $50{ }^{\circ} \mathrm{C}$. Both enzymes were added to achieve a ratio of $10 \mathrm{U} / \mathrm{mg}$ biomass. The mixtures were subsequently centrifuged $\left(15 \mathrm{~min}, 5000 \mathrm{~g}, 25^{\circ} \mathrm{C}\right)$ and the glucose content in the supernatant was measured using the glucose oxidase method [30]. SPS content was finally calculated multiplying the glucose content by 0.9 , taking into account the addition of a water molecule during enzymatic hydrolysis of the polyglucans. The analysis was done in triplicate.

\subsubsection{Chrysolaminarin}

Chrysolaminarin content was determined for Nannochloropsis sp., T. lutea, P. tricornutum, O. aurita and D. lutheri, using a modified version of the method described by Granum \& Myklestad (2002) [31]. Dry biomass was suspended in demineralized water, after which the cells were disrupted using UHPH at $250 \mathrm{MPa}$. Whereas two passes were used for full disruption of Nannochloropsis sp. cells, a single pass at $250 \mathrm{MPa}$ was sufficient for the other microalgae species. The disrupted microalgae were lyophilized and $\beta$-1,3-glucans were subsequently extracted with $0.05 \mathrm{M}$ sulfuric acid at $60^{\circ} \mathrm{C}$ for $10 \mathrm{~min}$. The extract was filtered using GF/C glass fiber filters and the glucose content was determined using the phenol-sulfuric acid method [32]. Glucose content was multiplied by 0.9 to quantify the chrysolaminarin content. Extraction and quantification of chrysolaminarin was performed in triplicate.

\subsubsection{Ash and minerals}

Approximately $20 \mathrm{mg}$ of biomass was ashed in a muffle furnace (Nabertherm Controller P330, Lilienthal, Germany), operating for $24 \mathrm{~h}$ at $550{ }^{\circ} \mathrm{C}$. The ashes were weighed and dissolved in $10 \mathrm{~mL}$ of ultrapure water (organic free, $18 \mathrm{M} \Omega \mathrm{cm}$ resistance). These solutions were then acidified with $0.1 \mathrm{~mL}$ of $65 \% \mathrm{HNO}_{3}$ and filtered through a $0.45 \mu \mathrm{m}$ syringe filter (Chromafil $^{\circledR}$ A-45/25, Macherey-Nagel, Duren, Germany). Mineral composition was determined using inductively coupled plasma optical emission spectrometry (ICP-OES, Perkin-Elmer Optima 3300 DV, Norwalk, CT, USA). Ash content and mineral composition were determined in triplicate. 


\section{ACCEPTED MANUSCRIPT}

\subsubsection{Cell wall related polysaccharides}

The extraction and characterization of CWPS and EPMS is described later in section 2.3. The total content of CWPS and EPMS was calculated from the monosaccharide and uronic acid content using Eq. 2, taking into account the addition of a water molecule to the dehydrosugar in a polysaccharide chain (Eq. 1):

$$
(\text { dehydrosugar })_{n}+n \cdot \mathrm{H}_{2} \mathrm{O} \rightarrow n \cdot \text { monosaccharide }
$$

Polysaccharide (\%) $=\sum\left(\frac{M M_{\text {dehydrosugar }}}{M M_{\text {monosaccharide }}} \times\right.$ monosaccharide $\left.(\%)\right)+\sum\left(\frac{M M_{\text {dehydrouronic acid }}}{M M_{\text {uronic acid }}} \times\right.$ uronic acid (\%) $)$

\subsection{Composition of cell wall related polysaccharides}

\subsubsection{Extraction}

A schematic representation of the procedure for extraction of EPMS and CWPS is shown in Fig. 1.

\subsubsection{Extraction of extracellular polymeric substances}

In the current study, cell wall related polysaccharides are extracted from dry biomass. Therefore, our definition of EPMS only includes the polymeric material of the external layer that is still attached to the dried cells, that can be secreted when resuspending the biomass in a simulated growth medium. The presence of an extracellular layer surrounding the cells in the dry biomass was visualized for $P$. cruentum (as indicated by the arrows in Fig. A-1, supplementary material).

A procedure was implemented for extraction of EPMS based on methods of Hanlon et al. (2006) and Patel et al. (2013) [33,34]. Dry biomass (1.5 g) was suspended in $30 \mathrm{~mL}$ of saline solution at $\mathrm{pH} 7.5$ to mimic cultivation conditions of the microalgae. All marine microalgae were suspended in $2.5 \% \mathrm{w} / \mathrm{v} \mathrm{NaCl}$, whereas the freshwater species C. vulgaris was suspended in $0.02 \% \mathrm{w} / \mathrm{v} \mathrm{NaCl}$. All suspensions were incubated for $16 \mathrm{~h}$ at $25^{\circ} \mathrm{C}$, allowing the EPMS to dissolve into the medium. Subsequently, suspensions were centrifuged $\left(10 \mathrm{~min}, 10000 \mathrm{~g}, 4^{\circ} \mathrm{C}\right)$, followed by a second centrifugation step of the supernatants (30 min, $17000 \mathrm{~g}, 4^{\circ} \mathrm{C}$ ) to completely separate the biomass from the medium. The integrity of the cells in the residual biomass was confirmed using light microscopy (Olympus BX-51, Optical Co.Ltd, Tokyo, Japan). The successful removal of EPMS was clearly observed for P. cruentum, since the extracellular 


\section{ACCEPTED MANUSCRIPT}

layers observed in the dry biomass had disappeared after the extraction of EPMS (Fig. A-2, supplementary information). Cold ethanol (95\% v/v) was added to the resulting supernatant to precipitate EPMS, ensuring a final ethanol concentration higher than $70 \% \mathrm{v} / \mathrm{v}$. The solution was vacuum filtered using MN 615 filter paper and the insoluble residue was extensively dialyzed against demineralized water for $48 \mathrm{~h}$ (Spectra/Por ${ }^{\circledR}$, MWCO 3.5 kDa, Spectrum Laboratories, CA, USA). Finally, the dialyzed EPMS extracts were lyophilized (Alpha 2-4 LSC plus, Christ, Osterode, Germany).

\subsubsection{Extraction of cell wall polysaccharides}

In the present study, CWPS are considered the structural polysaccharides that are strongly bound in the cell wall. In contrast with EPMS, CWPS are not secreted into the surrounding environment, but play an important structural role in microalgal cells such as providing resistance to turgor pressure. CWPS were extracted by isolating an alcohol insoluble residue according to McFeeters \& Armstrong (1984) [35], with the additional removal of lipids, SPS and proteins as demonstrated by several authors $[20,36,37]$.

The residual biomass, i.e. the pellets obtained in the two centrifugation steps in section 2.3.1.1, was resuspended in $100 \mathrm{~mL}$ MOPS buffer $(55 \mathrm{mM}, \mathrm{pH} 7)$. Cells were disrupted using UHPH at $250 \mathrm{MPa}$, applying four passes for the rigid microalgae Nannochloropsis sp. and C. vulgaris, while a single pass was used for the other microalgae species. Cold ethanol was added to the suspensions (> 70\% v/v), the mixtures were centrifuged $\left(10 \mathrm{~min}, 10000 \mathrm{~g}, 4{ }^{\circ} \mathrm{C}\right)$ and the pellet was recovered. Lipids were removed by a hexane:isopropanol (3:2 v/v) extraction, based on the method of Ryckebosch et al. (2013) [38]. Hexane:isopropanol (3:2) was chosen as extraction solvent instead of chloroform:methanol (1:1), as the latter solvent mixture can also remove some non-lipid substances from the microalgal biomass [39]. In short, $30 \mathrm{~mL}$ of hexane:isopropanol (3:2) was added to the pellet, mixed and centrifuged (10 min, 900g, $20^{\circ} \mathrm{C}$ ) to remove the upper solvent layer. This lipid extraction was repeated to obtain a defatted pellet. Afterwards, SPS were enzymatically removed using either endo- $\beta-1,3$-glucanase or a combination of $\alpha$ amylase and amyloglucosidase, depending on the type of SPS [37,40]. For removal of (floridean) starch or glycogen, the defatted pellet was resuspended in sodium acetate buffer $(140 \mathrm{mM}, \mathrm{pH} 4.5)$ and heated for $10 \mathrm{~min}$ at $100{ }^{\circ} \mathrm{C}$ to gelatinize the (floridean) starch. The low $\mathrm{pH}$ of 4.5 was used to avoid possible 


\section{ACCEPTED MANUSCRIPT}

degradation reactions of CWPS occurring at high temperatures, such as beta-elimination of pectic polysaccharides [41]. After gelatinization, the $\mathrm{pH}$ was adjusted to 5.2 and $\alpha$-amylase from Bacillus sp. (839 U/mg, Sigma-Aldrich) and amyloglucosidase from A. niger (300 U/mL, Sigma-Aldrich) were both added in a ratio of $1 \mathrm{U} / \mathrm{mg}$ initial biomass. The mixtures were incubated for $4 \mathrm{~h}$ at $60{ }^{\circ} \mathrm{C}$. To remove chrysolaminarin, the defatted pellet was resuspended in sodium acetate buffer $(100 \mathrm{mM}, \mathrm{pH} 4.5)$ and heated for $10 \mathrm{~min}$ at $100{ }^{\circ} \mathrm{C}$. Afterwards, $\mathrm{pH}$ was adjusted to 5 and endo- $\beta-1,3$-glucanase of barley (2500 U/mL, Megazyme) was added to achieve $400 \mathrm{U} / \mathrm{g}$ initial biomass and the mixture was incubated for

$4 \mathrm{~h}$ at $40{ }^{\circ} \mathrm{C}$. After enzymatic incubations, cold ethanol was added to all samples $(>70 \% \mathrm{v} / \mathrm{v})$, the suspensions were centrifuged $\left(10 \mathrm{~min}, 10000 \mathrm{~g}, 4{ }^{\circ} \mathrm{C}\right)$ and the pellets were recovered. Lastly, proteins were

removed enzymatically. Therefore, pellets were resuspended in phosphate buffer $(80 \mathrm{mM}, \mathrm{pH} 7.5)$ and Subtilisin A protease from B. licheniformis (12 U/mg, Sigma-Aldrich) was added to achieve $50 \mathrm{U} / \mathrm{g}$ initial biomass. The mixtures were incubated for $1 \mathrm{~h}$ at $60{ }^{\circ} \mathrm{C}$ and after addition of cold ethanol (> 70\% v/v), they were centrifuged $\left(10 \mathrm{~min}, 10000 \mathrm{~g}, 4{ }^{\circ} \mathrm{C}\right)$. The pellet was finally washed in acetone, vacuum filtered and dried overnight at $40{ }^{\circ} \mathrm{C}$. This residue was considered as CWPS. 


\section{ACCEPTED MANUSCRIPT}

\subsubsection{Quantification}

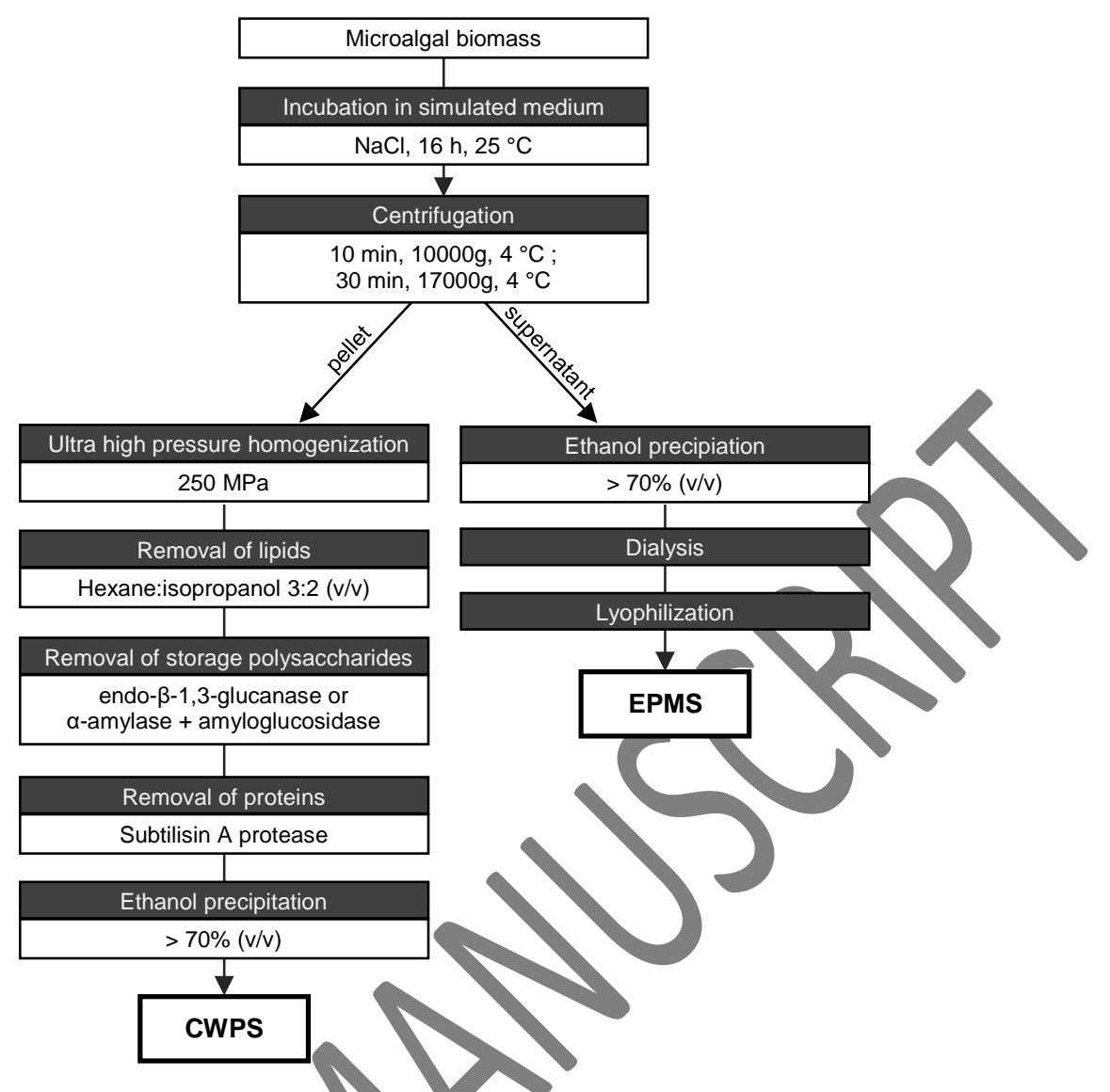

Fig. 1 Schematic overview of the extraction of extracellular polymeric substances (EPMS) and cell wall polysaccharides (CWPS).

\subsubsection{Quantification of monosaccharides and uronic acids}

Monosaccharide and uronic acid composition of CWPS and EPMS were determined according to De Ruiter et al. (1992) [42]. Polysaccharides were first hydrolyzed using methanolysis combined with trifluoroacetic acid (TFA) hydrolysis. The resulting monosaccharides and uronic acids were then quantified by high performance anion exchange chromatography combined with pulsed amperometric detection (HPAECPAD).

Methanolysis and TFA hydrolysis was performed as described by De Ruiter et al. (1992) [42]. Briefly, sample was dissolved in ultrapure water (organic free, $18 \mathrm{M} \Omega \mathrm{cm}$ resistance) in a concentration of $2 \mathrm{mg} / \mathrm{mL}$, of which $40 \mu \mathrm{L}$ was transferred to a pyrex tube and dried by $\mathrm{N}_{2}$ evaporation at $45^{\circ} \mathrm{C}$. Then, $2 \mathrm{~mL}$ of $2 \mathrm{M}$ methanolic $\mathrm{HCl}$ was added to the sample and the mixtures were incubated for $16 \mathrm{~h}$ at $80{ }^{\circ} \mathrm{C}$. The solvent 


\section{ACCEPTED MANUSCRIPT}

was removed by $\mathrm{N}_{2}$ evaporation at $30{ }^{\circ} \mathrm{C}$. Subsequently, $2 \mathrm{~mL}$ of $2 \mathrm{M}$ TFA was added to the tubes and incubated for $1 \mathrm{~h}$ at $121{ }^{\circ} \mathrm{C}$. After removing the solvent by $\mathrm{N}_{2}$ evaporation at $45^{\circ} \mathrm{C}$, the hydrolysate was dissolved in ultrapure water (organic free, $18 \mathrm{M} \Omega \mathrm{cm}$ resistance) and filtered through a $0.45 \mu \mathrm{m}$ syringe filter (Chromafil ${ }^{\circledR}$ A-45/25, Macherey-Nagel, Duren, Germany). The hydrolysis was performed in triplicate. Monosaccharides and uronic acids in the hydrolysates were identified and quantified by HPAEC-PAD, as described by Jamsazzadeh Kermani et al. (2014) [43]. A Dionex system (DX600) equipped with a GS50 gradient pump, a CarboPac ${ }^{\mathrm{TM}}$ PA20 column $(150 \times 3 \mathrm{~mm})$, a CarboPac ${ }^{\mathrm{TM}}$ PA20 guard column $(30 \times 3 \mathrm{~mm})$ and an ED50 electrochemical detector were used (Dionex, Sunnyvale, CA, USA). The detector was equipped with a reference $\mathrm{pH}$ electrode $(\mathrm{Ag} / \mathrm{AgCl})$ and a gold electrode. Equilibration was performed for 10 min with $100 \mathrm{mM} \mathrm{NaOH}$, after which $10 \mu \mathrm{L}$ of hydrolysate was injected. First, isocratic elution of monosaccharides was performed for $20 \mathrm{~min}$. In order to achieve a complete chromatographic separation of all monosaccharides analyzed, each sample was eluted using $0.5 \mathrm{mM} \mathrm{NaOH}$ as well as $15 \mathrm{mM} \mathrm{NaOH}$. Secondly, uronic acids were isocratically eluted with $500 \mathrm{mM} \mathrm{NaOH}$ for $10 \mathrm{~min}$.

Mixtures of commercial sugar standards (D-glucose, D-galactose, D-xylose, D-mannose, L-rhamnose, Larabinose, L-fucose, D-ribose, D-glucosamine, D-galacturonic acid and D-glucuronic acid) at varying concentrations (1-10 ppm) were used as external standards for identification and quantification. These standards were also subjected to the above-mentioned hydrolysis in order to correct for monosaccharide degradation during methanolysis and TFA hydrolysis.

\subsubsection{Quantification of sulfate groups}

Sulfate groups in the polysaccharide samples were quantified using the barium chloride-gelatin method of Dodgson \& Price (1962) [44]. Briefly, 2-5 mg of sample was hydrolyzed with $1 \mathrm{M} \mathrm{HCl}$ for $5 \mathrm{~h}$ at $100{ }^{\circ} \mathrm{C}$. The hydrolyzed sample was then incubated with $3 \%$ trichloroacetic acid and barium chloride-gelatin reagent for $15 \mathrm{~min}$ at $25^{\circ} \mathrm{C}$, and the absorbance was measured at $360 \mathrm{~nm}$. A standard curve was prepared with $\mathrm{K}_{2} \mathrm{SO}_{4}$. Samples were corrected for UV-absorbing materials formed during hydrolysis, which were determined in absence of barium as described by Dodgson \& Price (1962) [44]. The analysis was performed in triplicate. 


\subsection{Statistical analysis}

The data obtained are presented as the average of three measurements \pm standard error. Differences in biomass composition of different microalgae species were statistically analyzed using one-way ANOVA combined with Tukey's test for multiple comparison $(\mathrm{P}<0.05)$ with JMP statistical software (JMP Pro 12,

\section{Results and discussion}

\subsection{Characterization of the biomass composition}

Results obtained from the biochemical characterization of the microalgal biomasses are presented in

Table 1. These results are expressed as a percentage of dry matter, as they were corrected for the moisture contents $(1.5-8.2 \%)$. Generally, substantial differences were found in the biomass composition amongst different species, with each microalga showing a distinct biomass nutrient profile.

Table 1 Biochemical composition of microalgal biomasses, expressed as the average percentage of dry matter (\%) \pm standard deviation of triplicate measurements. (SPS: storage polysaccharides; CWPS: cell wall polysaccharides; EPS: extracellular polysaccharides; n.d.: not detected). The results were compared statistically (one-way ANOVA). Significant differences (Tukey test, $P<0.05)$ within each column are indieated with different letters $(n=3)$.

\begin{tabular}{|c|c|c|c|c|c|c|}
\hline & Lipids & ns & SPS & CWPS & EPS & Ash \\
\hline P. cruentum & & & $2.1 \pm 0.1 \mathrm{e}$ & $9.6 \pm 0.3 \quad$ b & $2.6 \pm 0.2 \mathbf{a}$ & $17.9 \pm 0.6 \mathbf{a}$ \\
\hline C. vulgaris & & 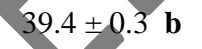 & $1.8 \pm 0.1 \mathbf{e}$ & $9.3 \pm 0.7 \quad \mathbf{b}$ & $0.5 \pm 0.1 \mathbf{c}$ & $6.7 \pm 0.1 \mathrm{~d}$ \\
\hline T. chuii & & $31.1 \pm 0.3 \mathrm{~d}$ & $7.8 \pm 0.2 \mathbf{b c}$ & $17.0 \pm 1.0 \mathbf{a}$ & n.d. & $14.5 \pm 0.3 \mathbf{b c}$ \\
\hline P. tricornutum & & $=0.4 \mathrm{de}$ & $5.2 \pm 0.7 \mathrm{~d}$ & $5.3 \pm 0.2 \mathbf{d}$ & n.d. & $15.9 \pm 0.9 \mathbf{b}$ \\
\hline O. aurita & & $20.2 \pm 0.1$ f & $21.7 \pm 0.6 \mathbf{a}$ & $7.4 \pm 0.3 \mathbf{c}$ & $1.2 \pm 0.1 \quad \mathrm{~b}$ & $14.1 \pm 0.6 \mathbf{c}$ \\
\hline Nannoc & & $35.1 \pm 0.8 \mathbf{c}$ & $5.9 \pm 0.5 \mathbf{c d}$ & $3.8 \pm 0.1 \mathbf{e}$ & n.d. & $6.1 \pm 0.9 \mathbf{d}$ \\
\hline Schizoch & & $10.2 \pm 0.1 \mathbf{g}$ & $6.3 \pm 1.1 \mathrm{bcd}$ & $6.9 \pm 0.4 \mathbf{c}$ & n.d. & $3.4 \pm 0.3 \mathbf{e}$ \\
\hline T. lutea & $2+$ & $29.8 \pm 0.7$ de & $7.3 \pm 0.4$ bc & $3.5 \pm 0.1 \mathbf{f}$ & n.d. & $13.5 \pm 0.6 \mathbf{c}$ \\
\hline D. lutheri & 12 & $21.9 \pm 0.3 \mathbf{f}$ & $7.2 \pm 0.8$ bc & $10.2 \pm 0.5 \mathbf{b}$ & n.d. & $13.0 \pm 0.4 \mathbf{c}$ \\
\hline & & $47.4 \pm 0.1 \mathbf{a}$ & $8.1 \pm 0.6 \quad b$ & $9.7 \pm 0.7 \quad \mathbf{b}$ & $0.7 \pm 0.1$ c & $4.5 \pm 0.2 \mathbf{e}$ \\
\hline
\end{tabular}

A large diversity is observed in terms of lipid content among all microalgae. A. platensis and C. vulgaris presented low lipid contents, making up 5.5\% and $6.6 \%$ of the biomass, respectively. Similar lipid contents were found in literature for biomasses of Arthrospira sp. (3.6-7.5\%) [1,3,45,46], while a wider range of fat contents was observed for C. vulgaris. Although some authors reported similar values of $5 \%$ oil for C. vulgaris [1,45], higher lipid contents $(13-20 \%)$ have also been found [3]. This could be related to 
differences in cultivation conditions, as it is known for Chlorophyceae (and oleaginous microalgae in general) that biomass composition can be selectively modified by adapting the cultivation conditions, such as nitrogen depletion and temperature [47]. In contrast, lipid content and composition of cyanobacteria are less affected by changes in cultivation conditions [8], confirming the smaller range of lipid contents found in literature for Arthrospira biomasses. In contrast to the former two species, Nannochloropsis sp., D. lutheri, T. lutea and P. tricornutum can be considered as lipid-rich microalgae, presenting lipid contents of $17-32 \%$. In fact, these microalgae species are considered among the most interesting sources of $\omega 3$-LCPUFA and similar values for total lipid content have been reported in literature [48]. In addition, a very high lipid content was observed for Schizochytrium sp., making up $74 \%$ of the dry biomass. It was microscopically confirmed that Schizochytrium sp. cells were completely filled with lipid bodies, as previously reported by Morita et al. (2006) [49]. Generally, lipid contents of Schizochytrium sp. are somewhat lower $(32-50 \%)$ [50,51], although a similar content of $73 \%$ has been reported by Liang et al. (2010) [52]. Finally, intermediate lipid contents $(11-13 \%)$ were observed for P. cruentum, T. chuii and O. aurita, corresponding to literature reports [48,53].

Proteins generally make up an important part of the biomass, being more than $20 \%$ for the investigated microalgae (except for Schizochytrium sp.). The highest protein contents were observed for A. platensis and C. vulgaris, comprising $47 \%$ and $39 \%$ of the dry biomass, respectively. These two species have been commercialized as a source of proteins, containing high amounts of essential amino acids [2]. Although some authors presented similar protein contents, approximately $38 \%$ for C. vulgaris and $39-46 \%$ for A. platensis [1,46], higher values (up to $70 \%$ for Arthrospira sp.) have also been reported $[3,6,54,55]$. However, it should be noted that part of this variation can be ascribed to different analytical approaches, such as the use of different correction factors for non-protein nitrogen in elemental analyses [5,6]. Large amounts of proteins were also found for lipid-rich microalgae species (D. lutheri, T. lutea, Nannochloropsis sp. and P. tricornutum), representing $22-35 \%$ of the biomass. Generally, the protein values obtained are in agreement with those reported in literature [1,6,26,56-58].

In contrast to most studies on microalgal biomass profiles, different types of carbohydrates were quantified separately in this study. According to literature, four types of SPS are present in the selected microalgae, 
being either starch, floridean starch, glycogen or chrysolaminarin. The three former SPS were analyzed by enzymatic hydrolysis, while the latter was extracted chemically, followed by quantification of the hydrolyzed glucose monomers. Relatively low SPS contents were observed for all microalgae species $(2-8 \%)$, with the exception of $O$. aurita biomass presenting $22 \%$ of chrysolaminarin. For biomasses of P. cruentum, Schizochytrium sp. and A. platensis, the values obtained correspond with previously reported SPS contents $[26,28,59]$. In contrast, the amount of SPS in C. vulgaris and P. tricornutumbiomass differs from those in literature [24,60], although only one article was encountered for each microalga reporting SPS contents grown under standard conditions. Typically, SPS are very sensitive to cultivation conditions and the time of harvesting. Whereas SPS contents are usually low in the exponential growth phase, they rapidly increase when nutrients are exhausted in the stationary phase. Similarly, cultivation in a nutrient depleted medium leads to accumulation of SPS $[25,57,61]$. The low amounts of SPS in these commercially obtained biomasses therefore suggest that cells were harvested in the late exponential phase, preserving the nutritional quality of the biomass in terms of protein content and lipid composition. Biomass of $O$. aurita was cultivated in open raceway ponds and could have experienced more stress in terms of nutrient heterogeneity or competition with other organisms, possibly resulting in higher chrysolaminarin contents compared to the other microalgae species.

Two fractions of cell wall related polysaccharides were extracted from the microalgal biomass. On the one hand, EPMS were comprised of polymers on the outer layer of the cell wall, which dissolved into the medium without disruption of the microalgal cells. EPMS were only obtained for four microalgae species (P. cruentum, O. aurita, A, platensis and C. vulgaris), implying that the other microalgae do not have a layer of extracellular polymers. These observations correspond to our previous study, in which an increased viscosity of the continuous serum phase was ascribed to the presence of extracellular polymers for these four microalgae species. In addition, the absence of EPMS in Nannochloropsis sp. and P. tricornutum was confirmed by that study, since no increased serum viscosity was observed for suspensions of these microalgae species [62]. The highest content of EPMS was found in P. cruentum, a red microalga which is known for its sulfated extracellular polysaccharides [13,63]. In addition, EPMS were also obtained for A. platensis, C. vulgaris and O. aurita. While EPMS have been previously reported for A. platensis $[64,65]$ 


\section{ACCEPTED MANUSCRIPT}

and $C$. vulgaris $[66,67]$, no information was found on the presence of EPMS in $O$. aurita. Furthermore, the absence of EPMS in Nannochloropsis sp., T. lutea and the fusiform type of P. tricornutum as seen in Table 1 was confirmed by other authors [68,69]. In contrast, although EPMS have been reported in literature for Tetraselmis sp. and Schizochytrium sp. [68,70], they were not observed in this study. It should be noted that EPMS were extracted starting from dried biomass. Therefore, the yield obtained in this study is probably lower than when EPMS are directly extracted from the cultivation medium, due tolosses of EPMS during harvesting steps. Although part of the extracellular polymers might have been secreted into the cultivation medium, the presence of unsecreted extracellular layers surrounding the microalgal cells was visualized using microscopy (Fig. A, supplementary material). Even if EPMS were partially lost during harvesting of the microalgae, the data obtained are relevant in the context of food applications, as microalgal biomass will be delivered in a dry form for use in food products to guarantee long term storage stability of these functional ingredients. In addition, Table 1 shows the content of extracellular polysaccharides (EPS), quantified as the sum of monosaccharides and uronic acids in the extracts, without considering other polymers such as proteins or co-extracted molecules like minerals and nucleic acids. However, when considering the weights of extracted EPMS, including other extracellular polymers, yields of $2.7-8.3 \%$ were obtained for these four microalgae species. Even though proteins were not quantified in EPMS samples (since they are accounted for in the total protein content of the biomasses), it can be inferred that they are present in all EPMS of the four microalgae species.

On the other hand, CWPS, which are structural polysaccharides constituting the cell wall, were extracted after removal of EPMS followed by disruption of the cells. Generally, CWPS make up around $10 \%$ of the microalgal biomass [54]. However, it is known that some microalgae contain a cell wall comprised of other (non-polysaccharide) substances, resulting in a reduced amount of polysaccharides in the cell wall. For instance, several authors have reported the presence of algaenan in the Nannochloropsis sp. cell wall, a resistant aliphatic biopolymer composed of ether-linked long alkyl chains of esterified monomers [71,72]. This could explain the low CWPS content found in Nannochloropsis sp. compared to the other microalgae species. Similarly, the cells of diatoms are surrounded by a silicified cell wall, called a frustule, which is coated with a layer of organic material [73]. This structure is likely present in $O$. aurita and was visualized 
by microscopic images in our previous study [62]. Although P. tricornutum is also classified as a diatom, not all morphotypes contain this siliceous skeleton. In fact, the ovoid form is the only morphotype presenting true silica valves, while the other morphotypes are poor in silica [73]. Thus, the lower amount of CWPS in P. tricornutum cannot be attributed to the presence of a frustule. Finally, the lowest amount of CWPS was found in T. lutea, representing only 3.5\% of the total biomass. It is known that Isochrysis sp. cells are easily disrupted, which is related to its weak cell wall structure [74]. Some authors even doubt the presence of a cell wall in Isochrysis sp., claiming that this microalga species only contains a plasma membrane around the cells [75]. However, the results obtained in this study imply that a cell wallayer of polysaccharides is present in T. lutea, but the low CWPS content suggests a rather small contribution, possibly related with its low resistance to mechanical disruption.

Finally, it was observed that all microalgal biomasses contain considerable amounts of minerals. Clear differences are observed between marine and freshwater microalgae. Whereas most of the marine microalgae presented high ash contents due to accumulation of minerals from the cultivation medium (13-18\% of the total biomass), the freshwater species C. vulgaris and A. platensis only presented ash contents of $6.7 \%$ and $4.5 \%$, respectively. The lowest ash content was observed for the heterotrophic Schizochytrium sp., representing only $3.4 \%$ of the total biomass, even though a higher value (11\% ash) was previously reported for biomass of S. limacinum [76]. Nevertheless, since Sun et al. (2014) stated that high lipid contents coincide with decreased ash contents in Schizochytrium sp. [77], it is not surprising that a low ash content was observed in this study. In addition, a low ash content was also observed in Nannochloropsis sp. biomass, even though this marine species was cultivated in a salt-rich medium. Nevertheless, similar values $(6-10 \%)$ have been previously reported by other authors [58,78]. In terms of mineral composition, each microalga species presented a typical mineral profile, as shown in Table 2. Generally, marine microalgae were rich in the monovalent cations sodium and potassium. In fact, sodium represented more than $60 \%$ of all minerals in biomasses of Nannochloropsis sp., Schizochytrium sp., T. lutea and D. lutheri. In contrast, the freshwater species A.platensis and C.vulgaris contained low amounts of sodium, representing less than $10 \%$ of the analyzed minerals in these biomasses. From a nutritional point of view, P. tricornutum has the most interesting mineral profile, possessing very high 
amounts of calcium and iron. Given that iron deficiency is considered as the most prevalent single nutritional deficiency in the world [79], P. tricornutum biomass shows great potential as an iron source in the human diet. In addition, this microalga presented substantial amounts of magnesium and manganese and a relatively low amount of sodium, which was also observed by Rebolloso-Fuentes et al. (2001) [80]. Biomasses of lower interest for nutritional purposes due to higher amounts of sodium. Sodium consumption is after all associated with increased blood pressure and cardiovascular diseases and a reduced sodium intake is therefore recommended [81]. Nevertheless, these three microalgae species, together with the freshwater species A. platensis and C. vulgaris, can generally be considered as good sources of minerals for human nutrition.

Table 2 Mineral composition of microalgal biomasses, expressed as the average \pm standard deviation of triplicate measurements. The results were compared statistically (one-way ANOVA). Significant differences (Tukey test, $P<0.05$ ) within each column are indicated with different letters $(n=3)$.

\begin{tabular}{|c|c|c|c|c|c|c|c|c|}
\hline & $\begin{array}{c}\mathrm{Na} \\
(\mathrm{mg} / \mathrm{g})\end{array}$ & $\begin{array}{c}\mathrm{K} \\
(\mathrm{mg} / \mathrm{g})\end{array}$ & $\begin{array}{c}\mathrm{Ca} \\
(\mathrm{mg} / \mathrm{g})\end{array}$ & & $(\mathrm{mg} / 100 \mathrm{~g})$ & $\begin{array}{c}\mathrm{Zn} \\
(\mathrm{mg} / \mathbf{1 0 0} \mathrm{g})\end{array}$ & $\begin{array}{c}\text { Mn } \\
(\mathrm{mg} / 100 \mathrm{~g})\end{array}$ & $\begin{array}{c}\mathrm{Cu} \\
(\mathrm{mg} / 100 \mathrm{~g})\end{array}$ \\
\hline P. cruentum & $27.1 \pm 1.4 \mathbf{a}$ & $17.5 \pm 2.7 \mathbf{a b}$ & & $\pm 0.5 \mathrm{a}$ & $131.1 \pm 3.3 \mathbf{b}$ & $6.9 \pm 0.5 \mathbf{a}$ & $8.7 \pm 0.4 \mathbf{b}$ & $0.9 \pm 0.1 \mathbf{a b}$ \\
\hline C. vulgaris & $2.4 \pm 0.2 \mathbf{e}$ & $12.2 \pm 0.2$ cde & & $.1 \mathrm{f}$ & $11.7 \pm 6.6$ ef & $1.8 \pm 0.8 \mathrm{de}$ & $1.6 \pm 0.8 \mathrm{de}$ & $0.6 \pm 0.1 \quad \mathbf{b}$ \\
\hline T. chuii & $10.1 \pm 0.9$ cd & $11.5 \pm 0.7$ & & $3.6 \pm 0.2 \mathrm{~d}$ & $49.0 \pm 6.4 \mathrm{~d}$ & $1.3 \pm 0.1$ ef & $8.0 \pm 1.0 \quad \mathbf{b}$ & $0.9 \pm 0.2 \mathbf{a b}$ \\
\hline P. tricornutum & $7.1 \pm 1.8 \mathbf{d}$ & & & $2 \mathrm{~d}$ & $240.6 \pm 14.0 \mathbf{a}$ & $2.9 \pm 0.3 \mathbf{c d}$ & $12.0 \pm 0.7 \mathbf{a}$ & $2.0 \pm 1.2 \mathbf{a}$ \\
\hline O. aurita & $18.8 \pm 2.3 \mathbf{b}$ & & & $3.5 \pm 0.3 \mathbf{d}$ & $19.2 \pm 2.7 \mathbf{e}$ & $0.3 \pm 0.01 \mathbf{f}$ & $11.9 \pm 1.4 \mathbf{a}$ & $0.2 \pm 0.02 \quad \mathbf{b}$ \\
\hline Nannochloropsis sp. & $12.8 \pm 0.9 \mathbf{c}$ & & & $1.9 \pm 0.2 \mathbf{e}$ & $7.3 \pm 3.0$ ef & $2.3 \pm 0.5 \mathrm{de}$ & $2.2 \pm 0.4 \mathbf{c d}$ & $0.5 \pm 0.2 \quad \mathbf{b}$ \\
\hline Schizochytrium sp. & $11.0 \pm 1.0$ & & 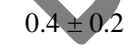 & $0.8 \pm 0.1 \mathbf{a}$ & $1.5 \pm 0.7$ ef & $3.9 \pm 0.01$ bc & $0.1 \pm 0.02 \mathbf{e}$ & $0.1 \pm 0.01 \quad \mathbf{b}$ \\
\hline T. lutea & $29.1 \pm 0.9$ & & 01 & $1.9 \pm 0.1 \mathbf{e}$ & $1.0 \pm 0.4 \mathbf{f}$ & $4.8 \pm 0.3 \mathbf{b}$ & $0.7 \pm 0.5 \mathrm{de}$ & $0.1 \pm 0.03 \mathbf{b}$ \\
\hline D. lutheri & 27.7 & & $3.7 \pm 0.9$ & $6.1 \pm 0.3 \mathbf{b}$ & $42.0 \pm 5.7 \mathbf{d}$ & $1.9 \pm 0.4 \mathbf{d e}$ & $1.4 \pm 0.3 \mathrm{de}$ & $0.4 \pm 0.1 \quad \mathbf{b}$ \\
\hline A. platensis & & $+0.9 \mathrm{~b}$ & $7.7 \pm 0.3$ & $4.6 \pm 0.2 \mathbf{c}$ & $93.3 \pm 6.1 \mathrm{c}$ & $1.9 \pm 0.5 \mathrm{de}$ & $3.8 \pm 0.1 \mathbf{c}$ & $0.5 \pm 0.03 \mathbf{b}$ \\
\hline
\end{tabular}

\subsection{Composition of cell wall related polysaccharides}

493 The aim of this study was to apply a universal procedure for extraction of the total cell wall related 494 polysaccharides followed by characterization of their monosaccharide and uronic acid composition. Table 3 presents the monosaccharide and uronic acid profiles of CWPS of the investigated microalgae, with each sugar expressed as a percentage of the total amount of monosaccharides and uronic acids. Diverse monosaccharide profiles were observed for the different microalgae species. All microalgae species presented at least five different monosaccharides in the CWPS extracts, suggesting that their cell walls are composed of heteropolymers or multiple types of polysaccharides. Glucose, galactose, xylose and mannose 


\section{ACCEPTED MANUSCRIPT}

were generally the most abundant monosaccharides, while the ratio of galacturonic and glucuronic acid was strongly dependent on the microalga species. The composition of the EPMS is shown in Table 4 for the four microalgae P. cruentum, $C$. vulgaris, $O$. aurita and A. platensis. As mentioned before, no EPMS could be extracted for the other microalgae species. Similar to CWPS, EPMS are considered heteropolysaccharides, containing both neutral monosaccharides and uronic acid residues. Finally, the sulfate content of both polysaccharide fractions is given in Table 5. All microalgae contained sulfated polysaccharides, although the degree of sulfation was generally low $(0.6-14 \%)$. However, it should be noted that the obtained cell wall fractions were not further purified and still contained some impurities such as ash and little amounts of proteins. As a consequence, sulfate contents of the purified cell wall related polysaccharides might be somewhat higher than the data presented in Table 5. Eyen though no detailed information was provided on the cultivation and harvesting conditions, the data obtained are expected to be representative for the cell wall related polysaccharides of microalgae of the investigated species. Although the amount of CWPS might be dependent on the cultivations conditions applied, it was previously shown that the composition of neutral monosaccharides was constant for Chlorella species when cultivated under different growth conditions, such as elevated $\mathrm{CO}_{2}$ concentration and nitrogen limitation $[37,82]$. The impact of different cultivation conditions on uronic acids in cell wall related polysaccharides might be different, as Cheng, Labavitch \& VanderGheynst (2015) indicated an increased uronic acid content under elevated $\mathrm{CO}_{2}$ supply [82]. However, to the best of our knowledge, no reports were found on uronic acids in the microalgal cell wall being affected by other cultivation parameters. 


\section{ACCEPTED MANUSCRIPT}

Table 3 Monosaccharide and uronic acid composition in cell wall polysaccharides (CWPS) of microalgae, expressed as the average percentage of total monosaccharides and uronic acids $(\%) \pm$ standard deviation of triplicate measurements $(n=3) .(n . d .:$ not detected).

\begin{tabular}{|c|c|c|c|c|c|}
\hline & P. cruentum & C. vulgaris & T. chuii & P. tricornutum & O. aurita \\
\hline Glucose & $30.5 \pm 1.1$ & $41.5 \pm 1.8$ & $28.9 \pm 4.1$ & $4.4 \pm 2.4$ & $11.1 \pm 0.8$ \\
\hline Galactose & $22.4 \pm 0.3$ & $8.6 \pm 0.2$ & $5.7 \pm 0.9$ & $3.8 \pm 0.9$ & $35.7 \pm 0.6$ \\
\hline Xylose & $27.8 \pm 2.4$ & n.d. & $5.3 \pm 0.7$ & $14.3 \pm 0.1$ & $9.3 \pm 0.6$ \\
\hline Mannose & $9.3 \pm 0.5$ & $34.8 \pm 7.6$ & $41.3 \pm 3.4$ & $46.4 \pm 1.3$ & $17.1 \pm 1.2$ \\
\hline Rhamnose & n.d. & $2.7 \pm 0.1$ & $1.0 \pm 0.2$ & $8.9 \pm 0.8$ & $3.2 \pm 1.1$ \\
\hline Arabinose & n.d. & n.d. & $0.8 \pm 0.2$ & n.d. & n.d. \\
\hline Fucose & n.d. & n.d. & $0.7 \pm 0.7$ & $2.5 \pm 0.3$ & \pm 0.6 \\
\hline Ribose & n.d. & $1.9 \pm 0.1$ & n.d & $2.9 \pm 1.2$ & 0.6 \\
\hline Glucosamine & $1.8 \pm 1.3$ & $2.9 \pm 0.1$ & n.d & & \\
\hline Galacturonic acid & $3.9 \pm 0.9$ & $3.3 \pm 0.2$ & $15.1 \pm 1.3$ & 2. & 2.6 \\
\hline Glucuronic acid & $4.3 \pm 0.1$ & $4.3 \pm 0.1$ & $1.2 \pm 0.2$ & & 1.0 \\
\hline
\end{tabular}

\section{Table 3 (continued)}

\begin{tabular}{|c|c|c|c|c|c|}
\hline & Nannochloropsis sp. & Schizochytrium sp. & T. lutea & D. lutheri & A. platensis \\
\hline Glucose & $75.8 \pm 4.9$ & $33.1 \pm 1.6$ & & $82.2 \pm 3.3$ & $49.8 \pm 5.8$ \\
\hline Galactose & $6.4 \pm 0.4$ & $29.0 \pm 3.5$ & & n.d. & $3.8 \pm 0.3$ \\
\hline Xylose & $3.5 \pm 0.4$ & $14.3 \pm 0.2$ & & $4.9 \pm 2.7$ & n.d. \\
\hline Mannose & $4.7 \pm 0.1$ & $20.5 \pm 3.4$ & & $6.2 \pm 0.3$ & $29.8 \pm 3.7$ \\
\hline Rhamnose & $3.0 \pm 0.1$ & n.d. & & n.d. & $6.7 \pm 0.9$ \\
\hline Arabinose & n.d. & & & $3.4 \pm 0.7$ & n.d. \\
\hline Fucose & $2.1 \pm 0.2$ & $n$ & & $0.8 \pm 0.4$ & n.d. \\
\hline Ribose & $4.5 \pm 0.1$ & & & $1.3 \pm 0.6$ & n.d. \\
\hline Glucosamine & n.d. & & n.d. & n.d. & $2.1 \pm 0.3$ \\
\hline Galacturonic acid & n.d. & & $4.1 \pm 3.3$ & n.d. & $5.6 \pm 2.9$ \\
\hline Glucuronic acid & n.d. & d. & $2.6 \pm 0.4$ & $1.2 \pm 0.3$ & $2.2 \pm 0.3$ \\
\hline
\end{tabular}

Table 4 Monosaccharide and uronic acid composition in extracellular polymeric substances (EPMS) of microalgae, expressed as the average percentage of total monosaccharides and uronic acids $(\%) \pm$ standard deviation of triplicate measurements $(n=3)$. (n.d.: not detected).

\begin{tabular}{lcccc} 
& P. cruentum & C. vulgaris & O. aurita & A. platensis \\
\hline Glucose & $35.4 \pm 5.6$ & $24.2 \pm 1.1$ & $2.1 \pm 0.3$ & $11.8 \pm 0.4$ \\
Galactose & $21.3 \pm 1.6$ & $17.3 \pm 0.5$ & $60.8 \pm 1.7$ & $11.1 \pm 0.6$ \\
Xylose & $29.3 \pm 1.8$ & $6.3 \pm 0.4$ & $10.6 \pm 0.2$ & $2.7 \pm 0.3$ \\
Mannose & $3.8 \pm 2.5$ & $19.1 \pm 0.5$ & $3.3 \pm 0.2$ & $1.7 \pm 0.1$ \\
Rhammose & n.d. & $11.0 \pm 0.3$ & $2.8 \pm 0.2$ & $29.1 \pm 1.4$ \\
Arabinose & n.d. & $1.9 \pm 0.1$ & n.d. & n.d. \\
Fucose & $1.3 \pm 0.1$ & $8.7 \pm 0.1$ & $15.9 \pm 0.5$ & $8.9 \pm 0.2$ \\
Ribose & n.d. & n.d. & n.d. & $25.8 \pm 0.8$ \\
Glucosamine & n.d. & n.d. & n.d. & n.d. \\
Galacturonic acid & n.d. & $3.3 \pm 0.1$ & $1.3 \pm 0.1$ & n.d. \\
Glucuronic acid & $8.9 \pm 0.3$ & $8.2 \pm 0.4$ & $3.2 \pm 0.1$ & $8.9 \pm 0.3$
\end{tabular}


Table 5 Sulfate content in cell wall polysaccharides (CWPS) and extracellular polymeric substances (EPMS) of microalgae, expressed as the average percentage of CWPS or EPMS $(\%) \pm$ standard deviation of triplicate measurements $(n=3)$. $(n . a .:$ not analyzed)

\begin{tabular}{lcc} 
& CWPS & EPMS \\
\hline P. cruentum & $4.24 \pm 0.12$ & $7.05 \pm 0.18$ \\
C. vulgaris & $1.14 \pm 0.06$ & $1.73 \pm 0.21$ \\
T. chuii & $1.18 \pm 0.10$ & n.a. \\
P. tricornutum & $6.89 \pm 0.17$ & n.a. \\
O. aurita & $10.89 \pm 0.61$ & $13.93 \pm 0.52$ \\
Nannochloropsis sp. & $6.43 \pm 0.11$ & n.a. \\
Schizochytrium sp. & $2.69 \pm 0.08$ & n.a. \\
T. lutea & $4.69 \pm 0.20$ & n.a. \\
D. lutheri & $5.99 \pm 0.14$ & n.a. \\
A. platensis & $0.64 \pm 0.11$ & $1.34 \pm 0.13$
\end{tabular}


glucose could also result from (partial) hydrolysis of cellulosic and hemicellulosic polymers. Chen et al. (2013) described the cell wall of Chlorophyta consisting of an inner cell wall layer, mainly composed of cellulose and hemicellulose, and an outer cell wall layer with a variable composition depending on the species [89]. However, discrepancies in cell wall structures of Chlorella sp. have been described in literature. This can be partly attributed to taxonomic revisions, resulting in a new definition of the Chlorella genus and therefore a transfer of previously assigned species to other genera [7]. Nevertheless, contrasting findings of several studies still result in a lack of clarity on the Chlorella sp. cell wall composition. Whereas some authors ascribe the rigidity of the cell wall to cellulose microfibrils [89,90], others attribute it to a chitin-like polysaccharide $[7,11,91]$. Given the low amount of glucosamine observed in this study, the latter statement cannot be confirmed based on our results. Moreover, even though the presence of hemicelluloses is mentioned by most authors, there is no consensus on the type of hemicelluloses in Chlorella sp. cell walls. In fact, the presence of either arabinomannans, arabinogalactans, glucomannans or xyloglucans was reported in various studies $[17,87,92]$. Furthermore, CWPS of C. vulgaris contained low amounts of sulfate groups. Although some authors reported substantial amounts of sulfate esters in certain species of the Chlorella genus [12,93], no reports were found on C. vulgaris. Finally, EPMS from C. vulgaris showed a very heterogeneous composition, containing seven monosaccharides and two uronic acids, with a low degree of sulfation. Whereas the values obtained are confirmed for EPMS of Chlorella sp. by some authors $[14,68]$, others show contrasting results $[12,94]$. It can thus be concluded that microalgae of the Chlorella genus show a very large diversity in cell wall composition, presenting different cell wall structures depending on the species and the strain.

Similar to C. vulgaris, mannose and glucose were the main monosaccharides in the CWPS of T. chuii. Several authors reported these monosaccharides in Tetraselmis sp., but together with high amounts of galactose [95-97]. In addition, appreciable amounts of galacturonic acid in combination with minor amounts of galactose, rhamnose, arabinose and fucose suggest the presence of pectic polysaccharides. In fact, Arora et al. (2012) have reported the presence of glucans, galactomannans and pectins in cell walls of $T$. indica [98]. It should be noted that the obtained monosaccharide composition probably does not provide the full carbohydrate profile of the T. chuii cell wall. In fact, Tetraselmis sp. cell walls are built up of thecae which 


\section{ACCEPTED MANUSCRIPT}

contain up to $80 \%$ of acidic polysaccharides, characterized as 3-deoxy-manno-2-octulosonic acid, 3-deoxy5-O-methyl-manno-2-octulosonic acid and 3-deoxy-lyxo-2-heptulosaric acid [7,99]. However, no attempts were made to quantify these keto-sugar acids in this study. Finally, a sulfate content of $1.2 \%$ was observed in CWPS of T. chuii, somewhat lower compared to previous studies [68,99].

CWPS of the diatom P. tricornutum consisted mainly of mannose and glucuronic acid, representing $60 \%$ of the total sugars. Several authors have previously identified a sulfated glucuronomannan as the most prominent polysaccharide present in P. tricornutum [97,100,101]. A sulfate content of $6.9 \%$ was obtained, corresponding to previous reports [93,100]. In addition, minor amounts of other monosaccharides, mainly xylose, rhamnose, glucose and galactose, suggest the presence of other hemicellulosic polymers in the cell wall of $P$. tricornutum [17]. Although some authors suggest that sulfated glucuronomannans are a conserved structural polymer in diatoms [101], this was not obvious from the CWPS composition of $O$. aurita, another diatom. A heterogeneous monosaccharide profile was found, mainly containing galactose, mannose, fucose and glucose. EPMS of $O$. aurita also presented high amounts of galactose and fucose, while mannose and glucose were only minor constituents of EPMS. Uronic acids accounted for $10 \%$ of the sugar composition in both fractions. In addition, high sulfate contents were found for CWPS and EPMS of O. aurita, being $11 \%$ and $14 \%$, respectively. As a consequence, cell wall related polysaccharides of $O$. aurita possess anionic characteristics and could therefore be an interesting source in terms of several functionalities.

CWPS of Nannochloropsis sp. consist of $75 \%$ glucose, together with minor amounts of other monosaccharides. This large fraction of glucose was previously observed by several authors and was ascribed to cellulose polymers [71,97,102]. Scholz et al. (2014) described the cell wall of $N$. gaditana as a bilayer structure, consisting of a cellulosic inner wall representing approximately $75 \%$ of the mass balance, protected by an outer algaenan layer [71]. The latter layer was not identified nor quantified in this study. It must be noted that microcrystalline cellulose is only partially hydrolyzed by methanolysis and TFA hydrolysis, with a recovery of only 30 to $50 \%$. This might be another explanation for the low amount of CWPS of Nannochloropsis sp. presented in Table 1. No uronic acids were present in Nannochloropsis sp., while a substantial amount of sulfate groups was observed. The latter results, in combination with low 
amounts of other monosaccharides, suggest the presence of sulfated polysaccharides in the Nannochloropsis sp. cell wall in addition to cellulose and algaenan. Only few studies investigated the cell wall composition of Schizochytrium sp., describing a thin noncellulosic cell wall with galactose as the principal monosaccharide [103,104]. In the current study, galactose was also observed, however together with glucose, mannose and xylose. The latter two monosaccharides have been previously reported in Thraustochytrium species. These fungi are phylogenetically related to Schizochytrium sp., based on the structure and formation of the cell wall in particular $[103,104]$. Furthermore, CWPS of Schizochytirium sp. presented a low degree of sulfation (2.7\%) and uronic acids were absent.

In CWPS of T. lutea, all monosaccharides were detected in substantial amounts, except for glucosamine. The largest fraction of CWPS was composed of glucose, mannose, arabinose and galactose. These were also the major monosaccharides observed in previous studies [95,97], although glucose represented $76 \%$ of the total sugar composition in the study of Brown (1991) [97]. However, that study reported on the overall polysaccharide composition, including the SPS chrysolaminarin. Since our results showed that T. lutea contained a large fraction of chrysolaminarin in comparison with the fraction of CWPS (Table 1), it is inferred that glucose is mainly attributed to chrysolaminarin, and only partially constituting the cell wall of T. lutea. Finally, the CWPS also contained sulfated polysaccharides, with similar sulfate contents as previously reported $(1.1-5.5 \%)$ [20]. Although D. lutheri also belongs to the Haptophyta, i.e. the same class as T. lutea, a different CWPS composition was observed for this microalga species. Glucose was found as the principal monosaccharide, while mannose, xylose and arabinose were present in low amounts. Arnold et al. (2015) reported that $D$. lutheri cell walls consist of small cellulose scales covered by an organic matrix of hemicellulose, mainly xyloglucans [105]. Moreover, a sulfate content of $6 \%$ was determined for CWPS of D. lutheri, indicating the presence of sulfated polysaccharides.

Finally, CWPS of the cyanobacterium A. platensis were mainly composed of glucose and mannose. In fact, these monosaccharides are typically found in the cell walls of cyanobacteria, together with minor amounts of galactose and xylose [106]. In addition, the observed amounts of rhamnose could result from spirulan polymers, a sulfated polysaccharide which was previously extracted from A. platensis [107]. It should be 


\section{ACCEPTED MANUSCRIPT}

noted that polysaccharides probably represent a small fraction of the cell wall, since cyanobacterial cells are typically covered by a peptidoglycan layer, a polymer composed of N-acetyl-glucosamine [106]. Surprisingly, only low amounts of glucosamine were detected in this study, which could be due to incomplete hydrolysis of peptidoglycan by methanolysis and TFA hydrolysis. In fact, some authors hypothesized that a harsher $\mathrm{HCl}$ hydrolysis procedure would result in a more complete hydrolysis of $\mathrm{N}$ acetyl-glucosamine containing polymers [17]. Furthermore, a heterogeneous monosaccharide profile was observed for EPMS of A. platensis, showing substantial amounts of rhamnose, ribose, glucose, galactose, fucose and glucuronic acid. These sugars have been previously reported for EPMS of A. platensis, but in different ratios [14,64]. Although several bioactivities are ascribed to specific sulfated polysaccharides of A. platensis $[14,107]$, it is assumed that these polymers only make up a small fraction of the cell wall related polysaccharides, since low degrees of sulfation were obseryed in both CWPS and EPMS $(0.6 \%$ and $1.4 \%)$.

\section{Conclusions}

This study compared the biomass profiles of ten microalgae species using a standardized protocol, mainly focusing on the composition of their cell wall related polysaccharides. A large diversity in biomass composition was demonstrated, allowing an appropriate selection of microalgae species towards specific applications. Nevertheless, some taxonomic similarities were observed. Microalgae belonging to the Haptophyta (T. lutea and D. lutheri) were characterized by high amounts of lipids and proteins, intermediate SPS and ash contents, and the absence of EPMS. In contrast, C. vulgaris and T. chuii (Chlorophyta) were mainly composed of proteins and CWPS, while lipids represented a smaller fraction of these biomasses. Less similarities were found among the two investigated diatoms, $P$. tricornutum and O. aurita, which might be ascribed to distinct cultivation conditions resulting in a high SPS content in O. aurita. Moreover, the presence of large amounts of structural components in most microalgae, such as EPS in P. cruentum or high protein contents in C. vulgaris and A. platensis, might explain the functionality of microalgal biomasses as potential gelling or thickening agents.

Generally, CWPS made up $10 \%$ of the microalgal biomass, however the contribution of other nonpolysaccharide substances to the cell wall could not be excluded. Extraction of EPMS was only successful 
for four microalgae species, implying that the other microalgae do not possess extracellular polymers. Even though CWPS and EPMS of all microalgae species were sulfated, their degree of sulfation was generally

\section{Acknowledgements}

The authors acknowledge the financial support of the Research Fund KULeuven (KP/14/004). T. Bernaerts and

L. Gheysen are PhD fellows funded by the Research Foundation Flanders (FWO). C. Kyomugasho is a postdoctoral researcher funded by the Onderzoeksfonds KU Leuven post-doctoral fellowship (PDM). We would

\section{References}

[1] A.P. Batista, L. Gouveia, N.M. Bandarra, J.M. Franco, A. Raymundo, Comparison of microalgal biomass profiles as novel functional ingredient for food products, Algal Res. 2 (2013) 164-173. doi:10.1016/j.algal.2013.01.004.

[2] S. Buono, A.L. Langellotti, A. Martello, F. Rinna, V. Fogliano, Functional ingredients from microalgae, Food Funct. 5 (2014) 1669-1685. doi:10.1039/C4FO00125G.

[3] M.K. Tokusoglu, Ö., Unal, Biomass nutrient profiles of three microalgae: Spirulina platensis, Chlorella vulgaris and Isochrysis galbana, J. Food Sci. 68 (2003) 1144-1148. doi:10.1111/j.13652621.2003.tb09615.x.

[4] Q. Hu, Environmental effects on cell composition, in: Handb. Microalgal Cult. Biotechnol. Appl. Phycol., Blackwell Publishing Ltd., 2004: pp. 83-93.

[5] S.O. Lourenço, E. Barbarino, P.L. Lavín, U.M. Lanfer Marquez, E. Aidar, Distribution of intracellular nitrogen in marine microalgae: Calculation of new nitrogen-to-protein conversion factors, Eur. J. Phycol. 39 (2004) 17-32. doi:10.1080/0967026032000157156.

[6] C.V. González López, M. del C. Cerón García, F.G. Acién Fernández, C.S. Bustos, Y. Chisti, J.M.F. Sevilla, Protein measurements of microalgal and cyanobacterial biomass, Bioresour. Technol. 101 
(2010) 7587-7591. doi:10.1016/j.biortech.2010.04.077.

[7] P.-H. Baudelet, G. Ricochon, M. Linder, L. Muniglia, A new insight into cell walls of Chlorophyta, Algal Res. 25 (2017) 333-371. doi:10.1016/j.algal.2017.04.008.

[8] W. Becker, Microalgae in human and animal nutrition, in: Handb. Microalgal Cult. Biotechnol. Appl. Phycol., Blackwell Publishing Ltd., 2004: pp. 312-351.

[9] E. Günerken, E. D’Hondt, M.H.M. Eppink, L. Garcia-Gonzalez, K. Elst, R.H. Wijffels, Cell disruption for microalgae biorefineries, Biotechnol. Adv. 33 (2015) 243-260. doi:10.1016/j.biotechadv.2015.01.008.

[10] L.S. Sierra, C.K. Dixon, L.R. Wilken, Enzymatic cell disruption of the microalgae Chlamydomonas reinhardtii for lipid and protein extraction, Algal Res. 25 (2017) 149-159. doi:10.1016/j.algal.2017.04.004.

[11] H.G. Gerken, B. Donohoe, E.P. Knoshaug, Enzymatic cell wall degradation of Chlorella vulgaris and other microalgae for biofuels production, Planta. 237 (2013) 239-253. doi:10.1007/s00425-012-17650 .

[12] M.F. de Jesus Raposo, A.M.M.B. de Morais, R.M.S.C. de Morais, Bioactivity and Applications of Polysaccharides from Marine Microalgae, in: Polysaccharides, Springer, 2015: pp. 1683-1727. doi:10.1007/978-3-319-16298-0.

[13] S. Arad, O. Levy-Ontman, Red microalgal cell-wall polysaccharides: biotechnological aspects, Curr. Opin. Biotechnol. 21 (2010) 358-364. doi:10.1016/j.copbio.2010.02.008.

[14] C. Delattre, G. Pierre, C. Laroche, P. Michaud, Production, extraction and characterization of microalgal and cyanobacterial exopolysaccharides, Biotechnol. Adv. 34 (2016) 1159-1179. doi:10.1016/j.biotechadv.2016.08.001.

[15] R.K. Henderson, A. Baker, S.A. Parsons, B. Jefferson, Characterisation of algogenic organic matter extracted from cyanobacteria, green algae and diatoms, Water Res. 42 (2008) 3435-3445. doi:10.1016/j.watres.2007.10.032.

[16] J.A. Raven, J. Beardall, Carbohydrate Metabolism and Respiration in Algae, in: Photosynth. Algae, 14th ed., Springer, 2003: pp.205-224. https://doi.org/10.1007/978-94-007-1038-2_10.

[17] D.W. Templeton, M. Quinn, S. Van Wychen, D. Hyman, L.M.L. Laurens, Separation and quantification of microalgal carbohydrates, J. Chromatogr. A. 1270 (2012) 225-234. doi:10.1016/j.chroma.2012.10.034

[18] M.F. de Souza, D. Santos Pereira, S. Pereira Freitas, E.P. da Silva Bon, M. Almenara Rodrigues, Neutral sugars determination in Chlorella: Use of a one-step dilute sulfuric acid hydrolysis with reduced sample size followed by HPAEC analysis, Algal Res. 24 (2017) 130-137. doi:10.1016/j.algal.2017.03.019.

[19] B. Becker, J.P.M.Lommerse, M. Melkonian, J.P. Kamerling, J.F.G. Vliegenhart, The structure of an acidic trisaccharide component from a cell wall polysaccharide preparation of the green alga Tetraselmis striata Butcher, Carbohydr. Res. 267 (1995) 313-321. doi:10.1016/0008-6215(94)003005.

[20] Y Sun, H. Wang, G. Guo, Y. Pu, B. Yan, The isolation and antioxidant activity of polysaccharides from the marine microalgae Isochrysis galbana, Carbohydr. Polym. 113 (2014) 22-31. doi:10.1016/j.carbpol.2014.06.058.

[21] M.A. Borowitzka, J. Beardall, J.A. Raven, The Physiology of Microalgae, Springer, 2016.

[22] H.H. Nguyen, A. Shpigelman, S. Van Buggenhout, K. Moelants, H. Haest, O. Buysschaert, M. Hendrickx, A. Van Loey, The evolution of quality characteristics of mango piece after pasteurization and during shelf life in a mango juice drink, Eur. Food Res. Technol. 242 (2016) 703-712. doi:10.1007/s00217-015-2578-8.

[23] E. Ryckebosch, K. Muylaert, I. Foubert, Optimization of an Analytical Procedure for Extraction of 
Lipids from Microalgae, J. Am. Oil Chem. Soc. 89 (2012) 189-198. doi:10.1007/s11746-011-1903-z.

[24] I. Brányiková, B. Maršálková, J. Doucha, T. Brányik, K. Bišová, V. Zachleder, M. Vítová, Microalgae - Novel Highly Efficient Starch Producers, Biotechnol. Bioeng. 108 (2011) 766-776. doi:10.1002/bit.23016.

[25] C. Yao, J. Ai, X. Cao, S. Xue, W. Zhang, Enhancing starch production of a marine green microalga Tetraselmis subcordiformis through nutrient limitation, Bioresour. Technol. 118 (2012) 438-444. doi:10.1016/j.biortech.2012.05.030.

[26] L. Qu, L.J. Ren, J. Li, G.N. Sun, L.N. Sun, X.J. Ji, Z.K. Nie, H. Huang, Biomass composition, lipid characterization, and metabolic profile analysis of the fed-batch fermentation process of two different docosahexanoic acid producing Schizochytrium sp. strains, Appl. Biochem. Biotechnol. 171 (2013) 1865-1876. doi:10.1007/s12010-013-0456-z.

[27] M. Brody, A.E. Vatter, Observations on Cellular Structures of Porphyridium cruentum, J. Biophys. Biochem. Cytol. 5 (1959) 289-294. doi:10.1083/jcb.5.2.289.

[28] R. De Philippis, C. Sili, M. Vincenzini, Glycogen and poly- $\beta$-hydroxybutyrate synthesis in Spirulina maxima, J. Gen. Microbiol. 138 (1992) 1623-1628. doi:10.1099/00221287-138-8-1623.

[29] D. Pleissner, N.T. Eriksen, Effects of phosphorous, nitrogen, and carbon limitation on biomass composition in batch and continuous flow cultures of the heterotrophic dinoflagellate Crypthecodinium cohnii, Biotechnol. Bioeng. 109 (2012) 2005-2016. doi:10.1002/bit.24470.

[30] B.V. McCleary, V. Solah, T.S. Gibson, Quantitative Measurement of Total Starch in Cereal Flours and Products, J. Cereal Sci. 20 (1994) 51-58. doi:10.1006/jers.1994.1044.

[31] E. Granum, S.M. Myklestad, A simple combined method for determination of $\beta$-1,3-glucan and cell wall polysaccharides in diatoms, Hydrobiologia. 477 (2002) 155-161. doi:10.1023/A:1021077407766.

[32] M.K. Dubois, K.A. Gilles, J.K. Hamilton, P.A. Rebers, F. Smith, Colorimetric Method for Determination of Sugars and Related Substances, Anal, Chem. 28 (1956) 350-356. doi:10.1021/ac60111a017.

[33] A.R.M. Hanlon, B. Bellinger, K. Haynes, G. Xiao, T. a. Hofmann, M.R. Gretz, a. S. Ball, a. M. Osborn, G.J.C. Underwood, Dynamics of extracellular polymeric substance (EPS) production and loss in an estuarine, diatom-dominated, microalgal biofilm over a tidal emersion-immersion period, Limnol. Oceanogr. 51 (2006) 79-93. doi:10.4319/10.2006.51.1.0079.

[34] A.K. Patel, C. Laroche, A. Marcati, A.V. Ursu, S. Jubeau, L. Marchal, E. Petit, G. Djelveh, P. Michaud, Separation and fractionation of exopolysaccharide from Porphyridium cruentum, Bioresour. Technol. 145 (2013) 345-350. doi:10.1016/j.biortech.2012.12.038.

[35] R.F. McFeeters, S.A. Armstrong, Measurement of Pectin Methylation in Plant Cell Walls, Anal. Biochem. 139 (1984) 212-217. doi:10.1016/0003-2697(84)90407-X.

[36] A. Kermanshahi-pour, T.J. Sommer, P.T. Anastas, J.B. Zimmerman, Enzymatic and acid hydrolysis of Tetraselmis suecica for polysaccharide characterization, Bioresour. Technol. 173 (2014) 415-421. doi:10.1016/j.biortech.2014.09.048.

[37] Y.-S, Cheng, Y. Zheng, J.M. Labavitch, J.S. VanderGheynst, The impact of cell wall carbohydrate composition on the chitosan flocculation of Chlorella, Process Biochem. 46 (2011) 1927-1933. doi:10.1016/j.procbio.2011.06.021.

[38] E. Ryckebosch, C. Bruneel, R. Termote-Verhalle, C. Lemahieu, K. Muylaert, J. Van Durme, K. Goiris, I. Foubert, Stability of omega-3 LC-PUFA-rich photoautotrophic microalgal oils compared to commercially available omega-3 LC-PUFA oils, J. Agric. Food Chem. 61 (2013) 10145-55. doi:10.1021/jf402296s.

[39] E. Ryckebosch, C. Bruneel, R. Termote-Verhalle, K. Muylaert, I. Foubert, Influence of extraction solvent system on extractability of lipid components from different microalgae species, Algal Res. 3 (2014) 36-43. doi:10.1016/j.algal.2013.11.001. 
[40] L.M. Milke, V.M. Bricelj, N.W. Ross, Changes in enzymatic activity during early development of bay scallops argopecten irradians and sea scallops Pacopecten magellanicus, Aquat. Biol. 14 (2011) 207216. doi:10.3354/ab00398.

[41] D.N. Sila, S. Van Buggenhout, T. Duvetter, I. Fraeye, A. De Roeck, A. Van Loey, M. Hendrickx, Pectins in Processed Fruits and Vegetables: Part II-Structure-Function Relationships, Compr. Rev. Food Sci. Food Saf. 8 (2009) 86-104. doi:10.1111/j.1541-4337.2009.00071.x.

[42] G. De Ruiter, H.A. Schols, A.G.J. Voragen, F.M. Rombouts, Carbohydrate Analysis of Water-Soluble Uronic Acid Containing Polysaccharides with High-Performance Anion-Exchange Chromatography Using Methanolysis Combined with TFA Hydrolysis Is Superior to Four Other Methods, Anal. Biochem. 207 (1992) 176-185. doi:10.1016/0003-2697(92)90520-H.

[43] Z. Jamsazzadeh Kermani, A. Shpigelman, C. Kyomugasho, S. Van Buggenhout, M.Ramezani, A.M. Van Loey, M.E. Hendrickx, The impact of extraction with a chelating agent under acidic conditions on the cell wall polymers of mango peel, Food Chem. 161 (2014) 199-207. doi:10.1016/j.foodchem.2014.03.131.

[44] K.S. Dodgson, R.G. Price, A Note on the Determination of the Ester Sulphate Content of Sulphated Polysaccharides, Biochem. J. 84 (1962) 106-110.

[45] L. Gouveia, A.C. Oliveira, Microalgae as a raw material for biofuels production, J. Ind. Microbiol. Biotechnol. 36 (2009) 269-274. doi:10.1007/s10295-008-0495-6

[46] K.H. Ogbonda, R.E. Aminigo, G.O. Abu, Influence of temperature and $\mathrm{pH}$ on biomass production and protein biosynthesis in a putative Spirulina sp., Bioresour. Technol. 98 (2007) 2207-2211. doi:10.1016/j.biortech.2006.08.028.

[47] V. Ördög, W.A. Stirk, P. Bálint, A.O. Aremu, A. Okem, C. Lovász, Z. Molnár, J. van Staden, Effect of temperature and nitrogen concentration on lipid productivity and fatty acid composition in three Chlorella strains, Algal Res. 16 (2016) 141-149. doi:10.1016/j.algal.2016.03.001.

[48] E. Ryckebosch, C. Bruneel, R. Termote-Verhalle, K. Goiris, K. Muylaert, I. Foubert, Nutritional evaluation of microalgae oils rich in omega-3 long chain polyunsaturated fatty acids as an alternative for fish oil, Food Chem. 160 (2014) 393-400. doi:10.1016/j.foodchem.2014.03.087.

[49] E. Morita, Y. Kumon, T. Nakahara, S. Kagiwada, T. Noguchi, Docosahexaenoic Acid Production and Lipid-Body Formation in Schizochytrium limacinum SR21, Mar. Biotechnol. 8 (2006) 319-327. doi:10.1007/s10126-005-5060-y.

[50] G. Wang, T. Wang, Characterization of Lipid Components in Two Microalgae for Biofuel Application, J. Am. Oil Chem. Soc. 89 (2012) 135-143. doi:10.1007/s11746-011-1879-8.

[51] W. Chen, P. Zhou, M. Zhang, Y. Zhu, X. Wang, X. Luo, Z. Bao, L. Yu, Transcriptome analysis reveals that up-regulation of the fatty acid synthase gene promotes the accumulation of docosahexaenoic acid in Schizochytrium sp. S056 when glycerol is used, Algal Res. 15 (2016) 83-92. doi:10.1016/j.algal.2016.02.007.

[52] Y. Liang, N. Sarkany, Y. Cui, J. Yesuf, J. Trushenski, J.W. Blackburn, Use of sweet sorghum juice for lipid production by Schizochytrium limacinum SR21, Bioresour. Technol. 101 (2010) 3623-3627. doi:10.1016/j.biortech.2009.12.087.

[53] F. Guihéneuf, M. Fouqueray, V. Mimouni, L. Ulmann, B. Jacquette, G. Tremblin, Effect of UV stress on the fatty acid and lipid class composition in two marine microalgae Pavlova lutheri (Pavlovophyceae) and Odontella aurita (Bacillariophyceae), J. Appl. Phycol. 22 (2010) 629-638. doi:10.1007/s10811-010-9503-0.

[54] E.W. Becker, Micro-algae as a source of protein, Biotechnol. Adv. 25 (2007) 207-210. doi:10.1016/j.biotechadv.2006.11.002.

[55] C. Safi, A.V. Ursu, C. Laroche, B. Zebib, O. Merah, P.-Y. Pontalier, C. Vaca-Garcia, Aqueous extraction of proteins from microalgae: Effect of different cell disruption methods, Algal Res. 3 (2014) 61-65. doi:10.1016/j.algal.2013.12.004. 
[56] M.J. Fernández-Reiriz, A. Perez-Camacho, M.J. Ferreiro, J. Blanco, M. Planas, M.J. Campos, U. Labarta, Biomass production and variation in the biochemical profile (total protein, carbohydrates, RNA, lipids and fatty acids) of seven species of marine microalgae, Aquaculture. 83 (1989) 17-37. doi:10.1016/0044-8486(89)90057-4.

[57] S. Xia, B. Gao, A. Li, J. Xiong, Z. Ao, C. Zhang, Preliminary Characterization, Antioxidant Properties and Production of Chrysolaminarin from Marine Diatom Odontella aurita, Mar. Drugs. 12 (2014) 4883-4897. doi:10.3390/md12094883.

[58] M.M. Rebolloso-Fuentes, A. Navarro-Pérez, F. García-Camacho, J.J. Ramos-Miras, J.L. GuilGuerrero, Biomass nutrient profiles of the microalga Nannochloropsis, J. Agric. Food Chem. 49 (2001) 2966-2972. doi:10.1021/jf0010376.

[59] S. Arad, O. Friedman, A. Rotem, Effect of nitrogen on polysaccharide production in a Porphyridium sp., Appl. Environ. Microbiol. 54 (1988) 2411-2414. doi:102411-04\$02.00/0.

[60] B.-H. Zhu, H.-P. Shi, G.-P. Yang, N.-N. Lv, M. Yang, K.-H. Pan, Silencing UDP-glucose pyrophosphorylase gene in Phaeodactylum tricornutum affects carbon allocation, N. Biotechnol. Article in (2015) 6-13. doi:10.1016/j.nbt.2015.06.003.

[61] S.M. Myklestad, Production, Chemical Structure, Metabolism, and Biological Function of the $(1 \rightarrow 3)$ Linked, $\beta 3$-D-Glucans in Diatoms, Biol. Oceanogr. 6 (1989) 313-326. doi:10.1080/01965581.1988.10749534.

[62] T.M.M. Bernaerts, A. Panozzo, V. Doumen, I. Foubert, L. Gheysen, K. Goiris, P. Moldenaers, M.E. Hendrickx, A.M. Van Loey, Microalgal biomass as a (multi)functional ingredient in food products: Rheological properties of microalgal suspensions as affected by mechanical and thermal processing, Algal Res. 25 (2017) 452-463. doi:10.1016/j.alga1.2017.05.014.

[63] V. Gloaguen, G. Ruiz, H. Morvan, A. Mouradi-Givernaud, E. Maes, P. Krausz, G. Strecker, The extracellular polysaccharide of Porphyridium sp. an NMR study of lithium-resistant oligosaccharidic fragments, Carbohydr. Res. 339 (2004) 97-103. doi:10.1016/j.carres.2003.09.020.

[64] L. Trabelsi, N.H. M'sakni, H. Ben Ouada, H. Bacha, S. Roudesli, Partial Characterization of Extracellular Polysaccharides Produced by Cyanobacterium Arthrospira platensis, Biotechnol. Bioprocess Eng. 14 (2009) 27-31. doi:10.1007/s12257-008-0102-8.

[65] R. Filali Mouhim, J.-F Cornet, T. Fontane, B. Fournet, G. Dubertret, Production, Isolation and Preliminary Characterization of the Exopolysaccharide of the Cyanobacterium Spirulina platensis, Biotechnol. Lett. 15 (1993) 567-572. doi:10.1007/BF00138541.

[66] O. Morineau-Thomas, P. Jaouen, P. Legentilhomme, The role of exopolysaccharides in fouling phenomenon during ultrafiltration of microalgae (Chlorella sp. and Porphyridium purpureum): Advantage of a swirling decaying flow, Bioprocess Biosyst. Eng. 25 (2002) 35-42. doi:10.1007/s00449-001-0278-1.

[67] R. Xiao, Y.Zheng, Overview of microalgal extracellular polymeric substances (EPS) and their applications, Biotechnol. Adv. 34 (2016) 1225-1244. doi:10.1016/j.biotechadv.2016.08.004.

[68] M.A. Guzman-Murillo, F. Ascencio, Anti-adhesive activity of sulphated exopolysaccharides of microalgae on attachment of red sore disease-associated bacteria and Helicobacter pylori to tissue culture cells, Lett. Appl. Microbiol. 30 (2000) 473-478. doi:10.1046/j.1472-765x.2000.00751.x.

[69] A.P. Desbois, M. Walton, V.J. Smith, Differential antibacterial activities of fusiform and oval morphotypes of Phaeodactylum tricornutum (Bacillariophyceae), J. Mar. Biol. Assoc. United Kingdom. 90 (2010) 769-774. doi:10.1017/S0025315409991366.

[70] K.J.L. Chang, C.M. Nichols, S.I. Blackburn, G.A. Dunstan, A. Koutoulis, P.D. Nichols, Comparison of Thraustochytrids Aurantiochytrium sp., Schizochytrium sp., Thraustochytrium sp., and Ulkenia sp. for Production of Biodiesel, Long-Chain Omega-3 Oils, and Exopolysaccharide, Mar. Biotechnol. 16 (2014) 396-411. doi:10.1007/s10126-014-9560-5.

[71] M.J. Scholz, T.L. Weiss, R.E. Jinkerson, J. Jing, R. Roth, U. Goodenough, M.C. Posewitz, H.G. 
Gerken, Ultrastructure and Composition of the Nannochloropsis gaditana Cell Wall, Eukaryot. Cell. 13 (2014) 1450-1464. doi:10.1128/EC.00183-14.

[72] F. Gelin, J.K. Volkman, C. Largeau, S. Derenne, J.S. Sinninghe Damsté, J.W. De Leeuw, Distribution of aliphatic, nonhydrolyzable biopolymers in marine microalgae, Org. Geochem. 30 (1999) 147-159. doi:10.1016/S0146-6380(98)00206-X.

[73] G. Francius, B. Tesson, E. Dague, V. Martin-Jézéquel, Y.F. Dufrêne, Nanostructure and nanomechanics of live Phaeodactylum tricornutum morphotypes, Environ. Microbiol. 10 (2008) 13441356. doi:10.1111/j.1462-2920.2007.01551.x.

[74] E. Pales Espinosa, M. Perrigault, J.E. Ward, S.E. Shumway, B. Allam, Microalgal Cell Surface Carbohydrates as Recognition Sites for Particle Sorting in Suspension-Feeding Bivalves, Biol. Bull. 218 (2010) 75-86. doi:10.1086/BBLv218n1p75.

[75] C.J. Zhu, Y.K. Lee, Determination of biomass dry weight of marine microalgae, J. Appl.Phycol. 9 (1997) 189-194. doi:10.1023/A:1007914806640.

[76] M.B. Johnson, Z. Wen, Production of Biodiesel Fuel from the Microalga Schizochytrium limacinum by Direct Transesterification of Algal Biomass, Energy Fuels. 23 (2009) 5179-5183. doi:10.1021/ef900704h.

[77] L. Sun, L. Ren, X. Zhuang, X. Ji, J. Yan, H. Huang, Differential effects of nutrient limitations on biochemical constituents and docosahexaenoic acid production of Schizochytrium sp., Bioresour. Technol. 159 (2014) 199-206. doi:10.1016/j.biortech.2014.02.106.

[78] J.L. Faeth, P.J. Valdez, P.E. Savage, Fast Hydrothermal Liquefaction of Nannochloropsis sp. To Produce Biocrude, Energy Fuels. 27 (2013) 1391-1398. doi:10.1021/ef301925d.

[79] F. Camara, M.A. Amaro, R. Barbera, G. Clemente, Bioaccessibility of minerals in school meals: Comparison between dialysis and solubility methods, Food Chem. 92 (2005) 481-489. doi:10.1016/j.foodchem.2004.08.009.

[80] M.M. Rebolloso-Fuentes, A. Navarro-Pérez, J.J. Ramos-Miras, J.L. Guil-Guerrero, Biomass nutrient profiles of the microalga Phaeodactylum tricornutum, J. Food Biochem. 25 (2001) 57-76. doi:10.1111/j.1745-4514.2001.tb00724.x.

[81] N.J. Aburto, A. Ziolkovska, L. Hooper, P. Elliott, F.P. Cappuccio, J.J. Meerpohl, Effect of lower sodium intake on health: systematic review and meta-analyses, Br. Med. J. 346 (2013) f1326. doi:10.1136/bmj.f1326.

[82] Y.S. Cheng, J.M.Labavitch, J.S. VanderGheynst, Elevated CO2 concentration impacts cell wall polysaccharide composition of green microalgae of the genus Chlorella, Lett. Appl. Microbiol. 60 (2015) 1-7. doi:10.1111/lam.12320.

[83] S. Geresh, S. (Malis) Arad, O. Levy-Ontman, W. Zhang, Y. Tekoah, R. Glaser, Isolation and charaeterization of poly- and oligosaccharides from the red microalga Porphyridium sp., Carbohydr. Res. 344 (2009) 343-349. doi:10.1016/j.carres.2008.11.012.

[84] S. Geresh, I. Adin, E. Yarmolinsky, M. Karpasas, Characterization of the extracellular polysaccharide of Porphyridium sp.: molecular weight determination and rheological properties, Carbohydr. Polym. 50 (2002) 183-189. doi:10.1016/S0144-8617(02)00019-X.

[85] S. Geresh, S. Arad, The Extracellular Polysaccharides of the Red Microalgae: Chemistry and Rheology, Bioresour. Technol. 38 (1991) 195-201. doi:10.1016/0960-8524(91)90154-C.

[86] E. Loos, D. Meindl, Composition of the cell wall of Chlorella fusca, Planta. 156 (1982) 270-273. doi:10.1007/BF00393735.

[87] Y. Shi, J. Sheng, F. Yang, Q. Hu, Purification and identification of polysaccharide derived from Chlorella pyrenoidosa, Food Chem. 103 (2007) 101-105. doi:10.1016/j.foodchem.2006.07.028.

[88] M. Blumreisinger, D. Meindl, E. Loos, Cell Wall Composition of Chlorococcal Algae, Phytochemistry. 22 (1983) 1603-1604. doi:10.1016/0031-9422(83)80096-X. 
[89] C. Chen, X. Zhao, H. Yen, S. Ho, C. Cheng, D.-J. Lee, F.-W. Bai, J.-S. Chang, Microalgae-based carbohydrates for biofuel production, Biochem. Eng. J. 78 (2013) 1-10. doi:10.1016/j.bej.2013.03.006.

[90] A. Gille, A. Trautmann, C. Posten, K. Briviba, A. Gille, A. Trautmann, C. Posten, K. Briviba, Bioaccessibility of carotenoids from Chlorella vulgaris and Chlamydomonas reinhardtii, Int. J. Food Sci. Nutr. 67 (2017) 507-513. doi:10.1080/09637486.2016.1181158.

[91] E. Kapaun, E. Loos, W. Reisser, Cell wall composition of virus-sensitive symbiotic Chlorella species, Phytochemistry. 31 (1992) 3103-3104. doi:10.1016/0031-9422(92)83453-6.

[92] S. Pieper, I. Unterieser, F. Mann, P. Mischnick, A new arabinomannan from the cell wall of the chlorococcal algae Chlorella vulgaris, Carbohydr. Res. 352 (2012) 166-176. doi:10.1016/j.carres.2012.02.007.

[93] S. Guzmán, A. Gato, M. Lamela, M. Freire-Garabal, J.M. Calleja, Anti-inflammatory and immunomodulatory activities of polysaccharide from Chlorella stigmatophora and Phaeodactylum tricornutum, Phyther. Res. 17 (2003) 665-670. doi:10.1002/ptr.1227.

[94] D. Kaplan, D. Christiaen, S.M. Arad, Chelating Properties of Extracellutar Polysaccharides from Chlorella spp., Appl. Environ. Microbiol. 53 (1987) 2953-2956.

[95] J.N.C. Whyte, Biochemical Composition and Energy Content of Six Species of Phytoplankton used in Mariculture of Bivalves, Aquaculture. 60 (1987) 231-241. doi.10.1016/0044-8486(87)90290-0.

[96] A. Schwenzfeier, P.A. Wierenga, H. Gruppen, Isolation and characterization of soluble protein from the green microalgae Tetraselmis sp., Bioresour. Technol. 102 (2011) 9121-9127. doi:10.1016/j.biortech.2011.07.046.

[97] M.R. Brown, The amino-acid and sugar composition of 16 species of microalgae used in mariculture, J. Exp. Mar. Bio. Ecol. 145 (1991) 79-99. doi:10.1016/0022-0981(91)90007-J.

[98] M. Arora, A.C. Anil, J. Delany, N. Rajarajan, K. Emami, E. Mesbahi, Carbohydrate degrading bacteria closely associated with Tetraselmis indica: influence on algal growth, Aquat. Biol. 15 (2012) 61-71. doi:10.3354/ab00402.

[99] B. Becker, M. Melkonian, J.P. Kamerling, The Cell Wall (Theca) of Tetraselmis striata (Chlorophyta): Macromolecular Composition and Structural Elements of the Complex Polysaccharides, J. Phycol. 34 (1998) 779-787. doi:10.1046/j.1529-8817.1998.340779.x.

[100] C.W. Ford, E. Percival, Carbohydrates of Phaeodactylum tricornutum. Part II.* A Sulphated Glucuronomannan, J. Chem. Soc. (1965) 7042-7046.

[101] T. Le Costaouëc, C. Unamunzaga, L. Mantecon, W. Helbert, New structural insights into the cell-wall polysaccharide of the diatom Phaeodactylum tricornutum, Algal Res. 26 (2017) 172-179. doi:10.1016/j.algal.2017.07.021.

[102] S. Baba Hamed, M.B. Baba Hamed, S. Kassouar, S.-M.E.-A. Abi Ayad, Physicochemical analysis of cellulose from microalgae Nannochloropsis gaditana, African J. Biotechnol. 15 (2016) 1201-1207. doi:10.5897/AJB2016.15321.

[103] G. Bahnweg, I. Jäckle, A New Approach to Taxonomy of the Thraustochytriales and Labyrinthulales, in: Biol. Mar. Fungi, Cambridge University Press, 1986: pp. 131-140.

[104] W.M. Darley, D. Porter, M.S. Fuller, Cell Wall Composition and Synthesis via Golgi-Directed Scale Formation in the Marine Eucaryote, Schizochytrium aggregatum, with a Note on Thraustochytrium sp., Arch. Microbiol. 90 (1973) 89-106. doi:10.1007/BF00414512.

[105] A.A. Arnold, B. Genard, F. Zito, R. Tremblay, D.E. Warschawski, I. Marcotte, Identification of lipid and saccharide constituents of whole microalgal cells by 13C solid-state NMR, Biochim. Biophys. Acta. 1848 (2015) 369-377. doi:10.1016/j.bbamem.2014.07.017.

[106] C. Bertocchi, L. Navarini, A. Cesàro, Polysaccharides from Cyanobacteria, Carbohydr. Polym. 12 (1990) 127-153. doi:doi.org/10.1016/0144-8617(90)90015-K.

[107] J.-B. Lee, T. Hayashi, K. Hayashi, U. Sankawa, M. Maeda, T. Nemoto, H. Nakanishi, Further 


\section{ACCEPTED MANUSCRIPT}

976

977

978

Purification and Structural Analysis of Calcium Spirulan from Spirulina platensis, J. Nat. Prod. 61 (1998) 1101-1104. doi:10.1021/np980143n.

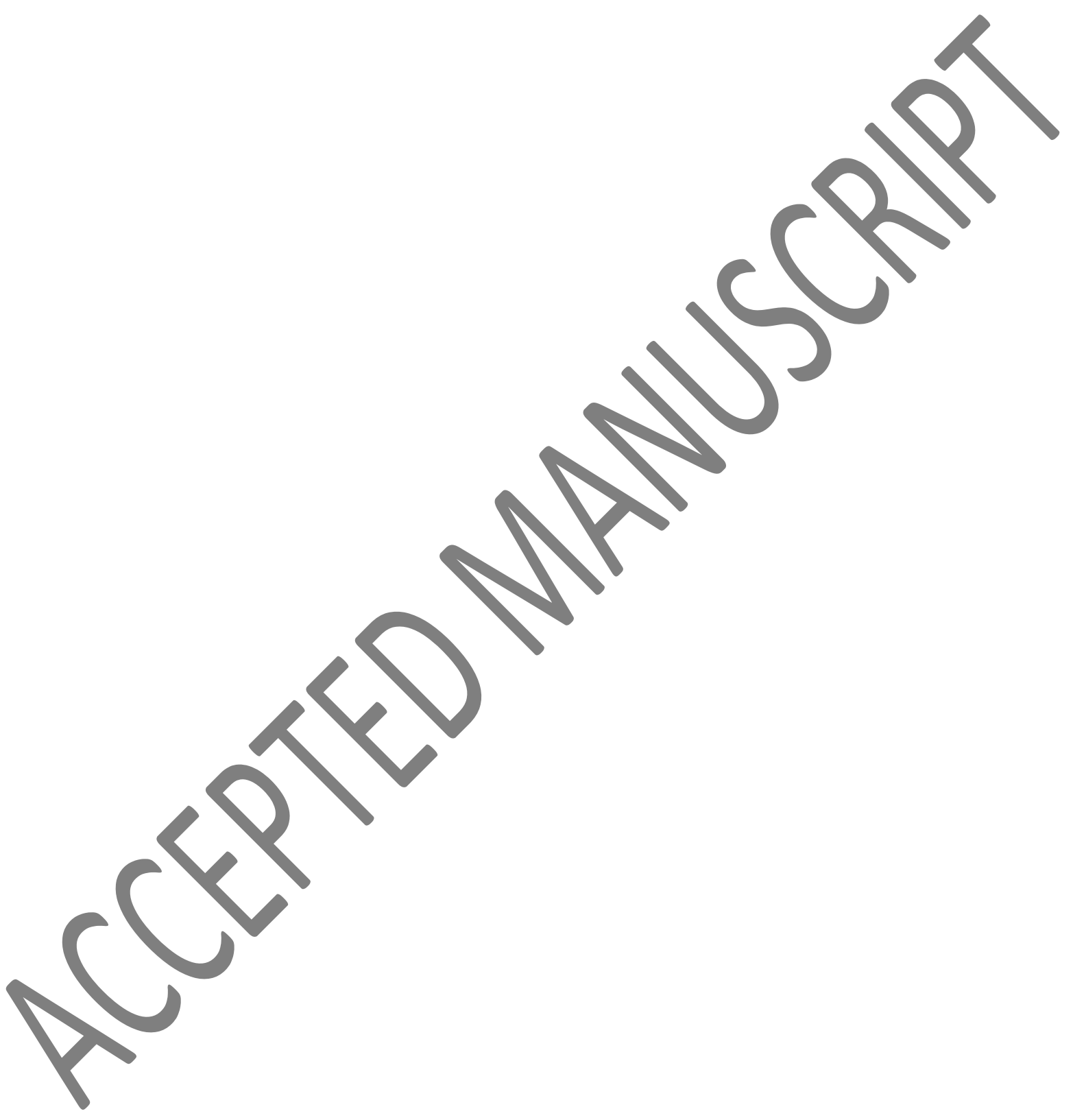

